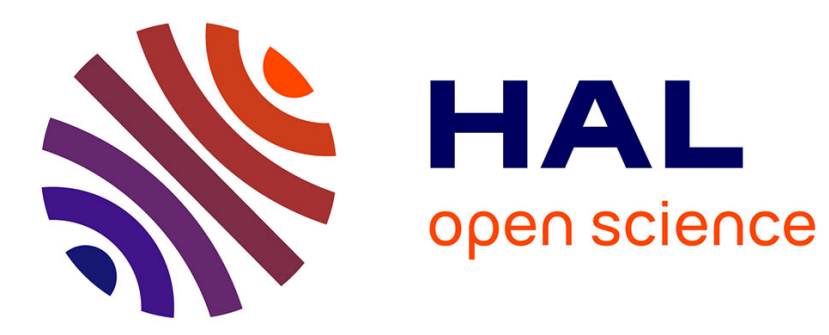

\title{
Different Strategies for Obtaining Enantiopure Hemicryptophanes
}

\author{
Cédric Colomban, Bastien Chatelet, Alexandre Martinez
}

\section{To cite this version:}

Cédric Colomban, Bastien Chatelet, Alexandre Martinez. Different Strategies for Obtaining Enantiopure Hemicryptophanes. Synthesis: Journal of Synthetic Organic Chemistry, 2019, 51 (10), pp.20812099. 10.1055/s-0037-1612420 . hal-02110985

\section{HAL Id: hal-02110985 \\ https://hal.science/hal-02110985}

Submitted on 23 Mar 2020

HAL is a multi-disciplinary open access archive for the deposit and dissemination of scientific research documents, whether they are published or not. The documents may come from teaching and research institutions in France or abroad, or from public or private research centers.
L'archive ouverte pluridisciplinaire HAL, est destinée au dépôt et à la diffusion de documents scientifiques de niveau recherche, publiés ou non, émanant des établissements d'enseignement et de recherche français ou étrangers, des laboratoires publics ou privés. 


\title{
Different Strategies for Obtaining Enantiopure Hemicryptophanes
}

\author{
Cédric Colomban \\ Bastien Châtelet
}

Alexandre Martinez ${ }^{*}$

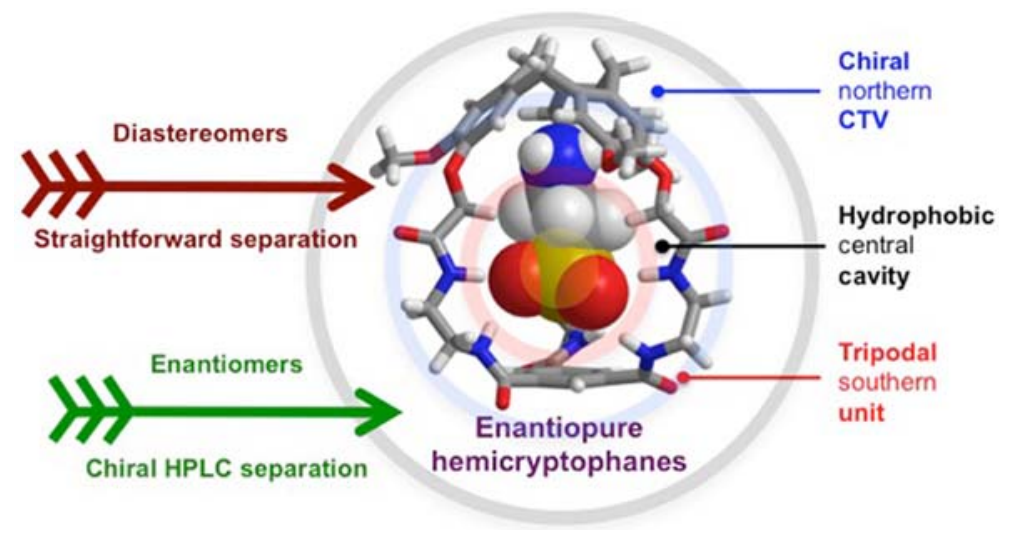

Abstract Hemicryptophanes have recently emerged as an attractive class of cages due to their interesting applications as supramolecular receptors and catalysts. Over the last decade, substantial advances have been made regarding the preparation of enantiopure versions of these synthetic receptors. Enantiopure hemicryptophanes are commonly obtained through the separation of diastereomers by chromatography, or by resolution of racemic mixtures using chiral HPLC. This short review summarizes the existing methods to access to these chiral organic architectures and discusses the benefits and drawbacks of each approach. Introduction

2 Enantiopure Hemicryptophanes Obtained by Introducing Additional Chiral Units and Separation of Diastereomers

2.1 Synthesis by Means of Intramolecular Macrocyclization Reactions

$2.2[1+1]$ Coupling of the CTV and the Southern Part

3 Enantiopure Hemicryptophanes Obtained by Means of Chiral HPLC Resolution of Enantiomers

3.1 Resolution of Hemicryptophane Racemates

3.2 Resolution of CTV-Based Precursor Racemates

4 Conclusion

Key words hemicryptophanes, chiral recognition, resolution, cyclotriveratrylene, supramolecular chemistry

\section{Introduction}

Chirality plays a crucial role in numerous biochemical processes of living systems, such as enzymatic catalysis and the recognition of neurotransmitters and carbohydrates by natural receptors. Based on the 'lock and key' model proposed by E. Fischer, artificial receptors have been developed to mimic these stereoselective molecular associations and recognition phenomena. ${ }^{1}$ Enantiopure molecular containers, presenting a well-defined cavity suitable for the stereo- selective complexation of chiral guests, have found numerous applications ranging from fundamental to applied fields of chemical sciences. ${ }^{2}$ Two main strategies have been followed to build enantiopure molecular receptors, involving either covalent or self-assembled approaches. On one hand, enantiopure self-assembling systems, like coordination cages, can be obtained after a few synthetic steps, and provide a chiral inner space designed for the binding of appropriate guests. ${ }^{3-9}$ On the other hand, enantiopure covalent receptors, the synthesis of which is often more tedious than their self-assembled counterparts, have emerged as an important class of artificial receptors. It is in this last category that calixarenes, ${ }^{10}$ cavitands, ${ }^{11}$ resorcinarenes, ${ }^{12}$ foldamers, ${ }^{13}$ cryptophanes, ${ }^{14}$ cyclodextrins, ${ }^{15}$ molecular baskets, ${ }^{16}$ etc. have shown impressive results toward chiral recognition and enantioselective catalysis. The chirality of these receptors is either due to the introduction of a chiral unit in their structures (for example, a stereogenic center or a sub-unit presenting axial chirality), or to the inherent chirality of the host arising from the bowl shape of its molecular scaffold. ${ }^{11 a, 17}$ This review is designed to establish a 'stateof-the-art' of the existing strategies that can be followed to synthesize, purify, and characterize a specific class of enantiopure covalent cages named hemicryptophanes. Studies related to any other class of chiral covalent hosts are beyond the scope of this review, which is aimed at triggering the reader's interest in the emerging hemicryptophane architectures.

Compared to cryptophanes, ${ }^{14}$ which combine two cyclotriveratrylene (CTV) units, hemicryptophanes associate a CTV moiety with another $C_{3}$ symmetrical unit. Their heteroditopic character has allowed for their use as receptors, supramolecular catalysts, and molecular switches. ${ }^{18}$ The CTV moiety, which constitutes the northern part of these 


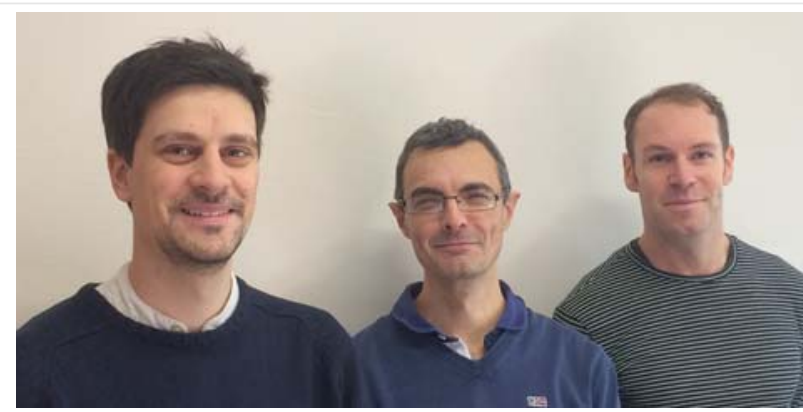

Cédric Colomban (left) was born in Briançon (France) in 1986. He studied organic and bio-inorganic chemistry at Joseph Fourier University (Grenoble, France). He completed his Ph.D. studies on bio-inspired catalysis in 2014 at University Claude Bernard (Lyon, France), under the guidance of Dr. Alexander Sorokin and Dr. Pavel Afanasiev. He undertook his first postdoctoral studies with Prof. Miquel Costas and Dr. Xavi Ribas at the University of Girona (Spain) (2015-2017) on self-assembled supramolecular cages. He is currently pursuing postdoctoral studies in the group of Prof. Alexandre Martinez on catalysis in the confined space of molecular cages.

Alexandre Martinez (middle) obtained his Ph.D. from the University of Toulouse (France) in 2004 for his studies on asymmetric oxidation under the supervision of Dr. B. Meunier. He then undertook postdoctoral studies on the theme of supramolecular chemistry in 2004-2005 at the University of Geneva (Switzerland) under the supervision of Prof. J. Lacour. He joined the Ecole Normale Supérieure de Lyon (France) in 2006 as a lecturer in the team of Dr. J.-P. Dutasta. He then obtained the position of Full Professor at the Ecole Centrale Marseille (France) in 2014. His research is in the field of stereochemistry, catalysis, and supramolecular chemistry, and he is particularly interested in hemicryptophanes as host molecules.

Bastien Chatelet (right) gained his Ph.D. from the École Normale Supérieure de Lyon (France) in 2013 under the supervision of Dr. Véronique Dufaud. He studied the confinement of Verkade's superbases and their conjugate acids, the azaphosphatranes, in hemicryptophane structures. He then completed postdoctoral work in the group of Prof. Guy Bertrand at the University of San Diego (USA). In 2016, he obtained a lecturer position at the École Centrale Marseille (France) in the group of Prof. A. Martinez. He is currently working on molecules with a phosphorus atom confined in hemicryptophanes and investigating their use as catalysts.

cages, is an inherently chiral unit with a $M$ or $P$ configuration, ${ }^{19}$ whereas their southern part commonly aims at introducing inner functionalities (Figure 1). It should be noted that when an enantiomer $(M$ or $P$ ) of a CTV unit is not closed at its lower part (open-shell structure), it can racemize. Indeed, these atropoisomers typically display energy barriers for racemization in the range of $112 \mathrm{~kJ} \mathrm{~mol}^{-1}$ at 293 $\mathrm{K}$, corresponding to half-life times of several months at this temperature. ${ }^{18,19}$ The absolute configuration of the CTV unit is usually assigned by comparison of the experimental electronic circular dichroism (ECD) spectrum with the calculated ECD spectrum of a benchmark CTV, as previously reported by Collet and co-workers ${ }^{19 b}$ for other CTV derivatives. Indeed, the ECD spectra of CTV-based compounds present an exciton pattern roughly centered on the isotropic absorption of the ${ }^{1} \mathrm{~L}_{\mathrm{A}}(240 \mathrm{~nm})$ transition with the sign being poorly sensitive to the nature of the substituents, allowing for the convenient assignment of the absolute configuration of the CTV moiety. ${ }^{19 \mathrm{~b}}$ The first synthesis of a (racemic) hemicryptophane cage was reported in 1982 by Collet and Lehn. ${ }^{18 a}$ However, it was not until 2005 that the first synthesis of an enantiopure hemicryptophane was described by Crassous and Dutasta (Figure 1). ${ }^{20}$ The reported strategy involved the introduction of stereogenic centers in order to form diastereomers which can be separated by chromatography. Another approach, based on the resolution of racemic mixtures of either key CTV intermediates or final molecular cages, has also been recently developed. The latter approach turns out to be promising as it can easily provide the desired enantiopure cages on gram scale. The first part of this review will be devoted toward the synthesis of enantiopure hemicryptophanes by association of racemic CTV units with chiral enantiopure moieties and the subsequent separation of the resulting diastereomeric cages. The second part deals with the use of chiral HPLC to resolve racemic mixtures of CTV or cages, allowing for an easier access to enantiopure hemicryptophane receptors.

\section{Enantiopure Hemicryptophanes Obtained by Introducing Additional Chiral Units and Separation of Diastereomers}

Enantiopure hemicryptophanes can be obtained by different strategies. Among them, introducing chiral centers with controlled stereochemistry on the hemicryptophane structure allows for the formation of diastereomers and avoids the resolution of enantiomers. However, most of the

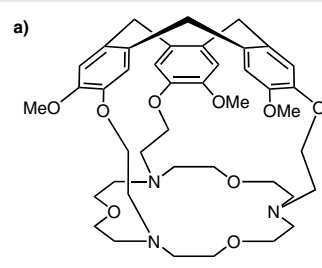

(M)

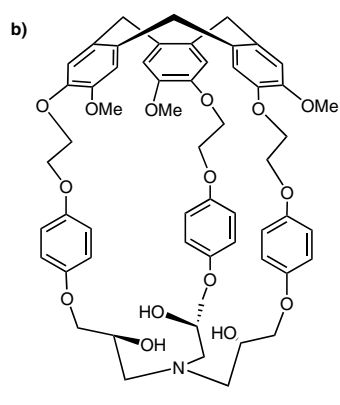

$(P)-(S, S, S)$

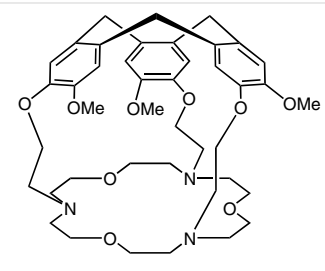

$(P)$
Figure 1 Structures of (a) the first hemicryptophane synthesized in 1982 by Collet and Lehn (racemic mixture), and (b) the first enantiopure hemicryptophane reported by Crassous and Dutasta in 2005 
time, this strategy involves more complicated synthetic pathways.

Hemicryptophanes with additional chiral groups grafted onto the chiral CTV unit can be obtained following two methods:

(i) By intramolecular macrocyclization reactions (commonly called the 'template approach') where the synthesis starts from the south of the molecule by the introduction of the platform, the linkers (bearing stereogenic units), and finally the veratryl moieties (at the northern side); a final intramolecular Friedel-Crafts alkylation generates the chiral CTV unit and closes the hemicryptophane (Figure 2a).

(ii) By coupling a racemic mixture of a preformed CTV with another $C_{3}$ symmetrical unit appended with three chiral enantiopure linkers (Figure $2 \mathrm{~b}$ ).

This section will be divided into two parts. The first part deals with the synthesis of enantiopure hemicryptophanes possessing stereogenic centers or sub-units presenting axial chirality, through intramolecular macrocyclization reactions. The second part will describe the synthesis of enantiopure hemicryptophanes starting from preformed CTV units.

\subsection{Synthesis by Means of Intramolecular Macro- cyclization Reactions}

In 2005, Crassous and Dutasta originally reported the first synthesis of an enantiopure hemicryptophane bearing stereogenic centers by introducing a chiral trialkanolamine moiety at the southern part of the cage. ${ }^{20}$ These compounds are of great interest due to their potential use as ligands for the endohedral coordination of metal cations in an enantiomerically pure environment. The enantiopure cage compounds 8 and $\mathbf{9}$ were obtained by applying an eight-step synthetic strategy starting from the reaction of vanillyl alcohol with dibromoethane in EtOH, which afforded compound $\mathbf{1}$ (Scheme 1 ).

Alcohol $\mathbf{1}$ is then protected with THP to give $\mathbf{2}$ with an overall yield of $27 \%$. Allyloxyphenol is then O-alkylated by compound 2 in the presence of a base $\left(\mathrm{Cs}_{2} \mathrm{CO}_{3}\right)$ in DMF to give 3 in 75\% yield. Deprotection of $\mathbf{3}$ into the phenol derivative $\mathbf{4}$, followed by its reactions with enantiopure $R$-glycidyl nosylate provided the epoxide $\mathbf{5}$ in an excellent overall yield of $87 \%$. The subsequent nucleophilic substitution of $\mathbf{5}$ with ammonia leads to the primary amine 6 . Compound 7 is then obtained by reaction of $\mathbf{6}$ with 2 equivalents of the epoxide $\mathbf{5}$, followed by an acetylation reaction. The latter synthetic step aims at decreasing the overall polarity of the cage precursor, leading to an easier purification of 7 by col-

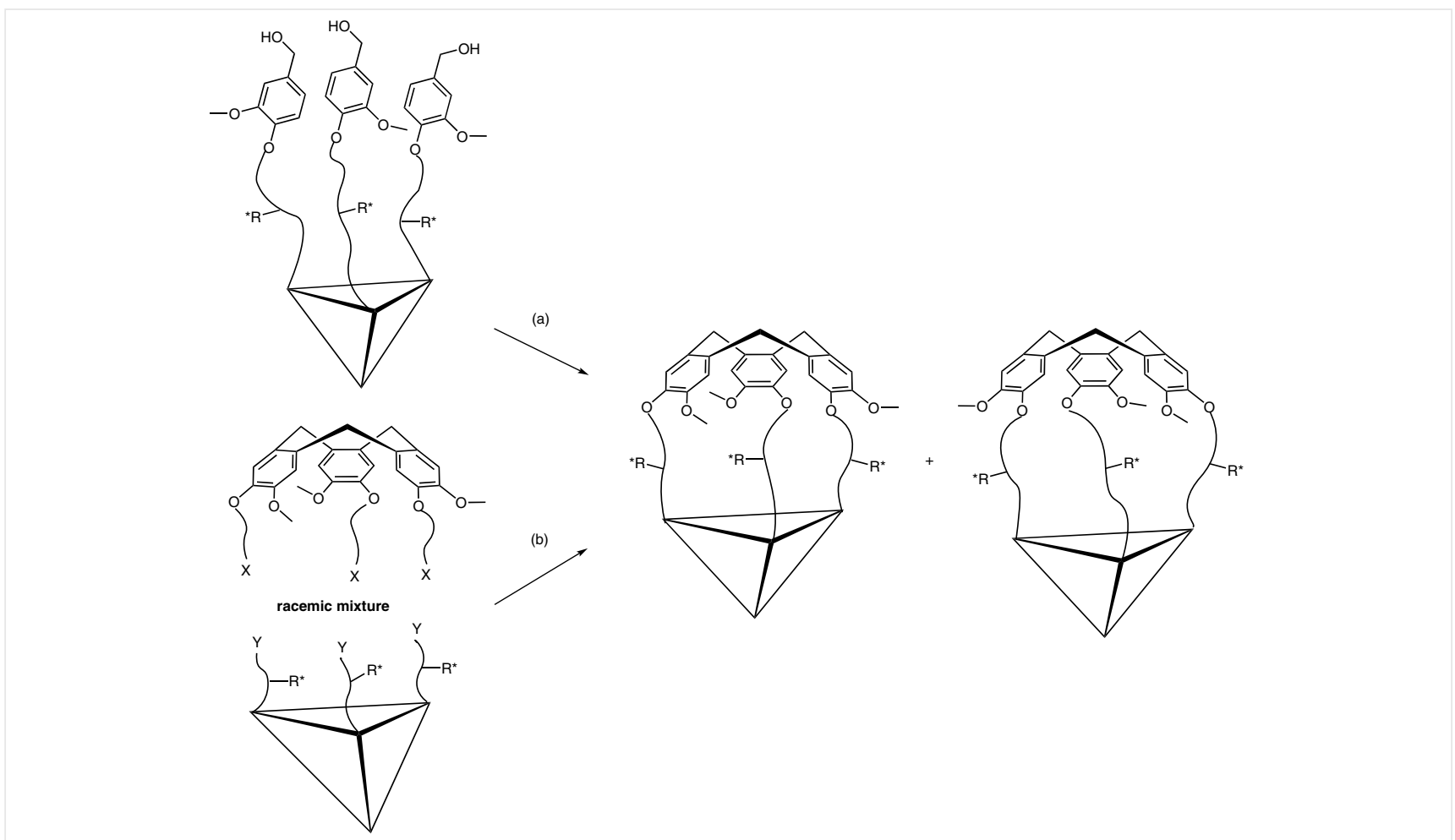

Figure 2 Synthetic strategies for the construction of hemicryptophanes bearing chiral groups: (a) by formation of the CTV unit; (b) by [1+1] coupling of the north and south parts 

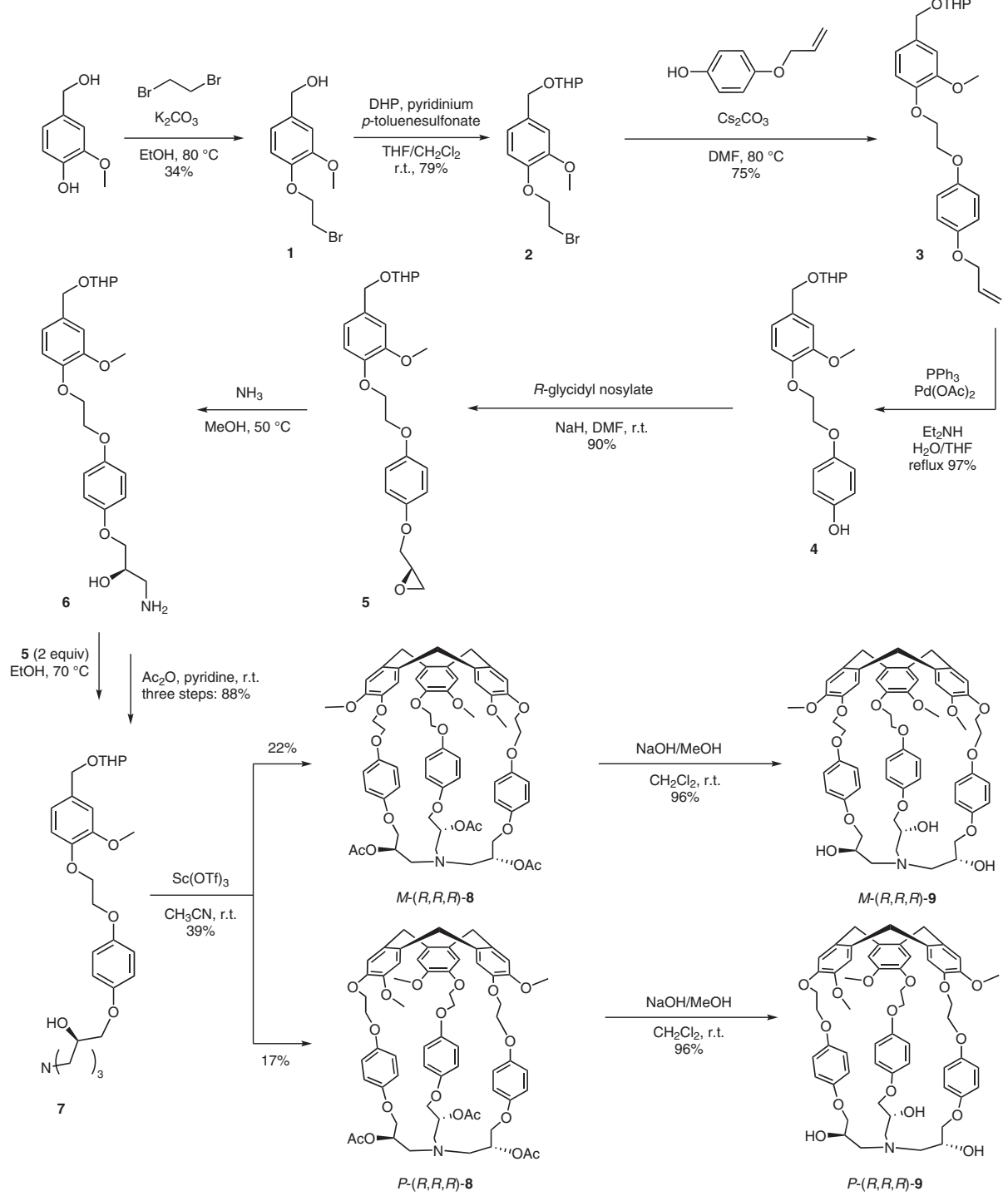

Scheme 1 Synthesis of hemicryptophanes $M-(R, R, R)-\mathbf{9}$ and $P-(R, R, R)-\mathbf{9}$ bearing trialkanol moieties

umn chromatography. Formation of the capsule $(R, R, R)-\mathbf{8}$ was achieved through the cyclization of the intermediate 7 in $\mathrm{CH}_{3} \mathrm{CN}$ catalyzed by the Lewis acid scandium triflate $\left[\mathrm{Sc}(\mathrm{OTf})_{3}\right]$ to yield to the diastereomers $P-(R, R, R)-\mathbf{8}$ and $M$ $(R, R, R)-8$, which could be separated by column chromatography. Finally, the targeted enantiopure cages $P-(R, R, R)-\mathbf{9}$ and $M-(R, R, R)-\mathbf{9}$ were obtained by deprotection of the hydroxy groups using methanolic $\mathrm{NaOH}$. Furthermore, it should be noted that the other diastereomeric pairs $P$ $(S, S, S)-\mathbf{8} / M-(S, S, S)-\mathbf{8}$ and $P-(S, S, S)-\mathbf{9} / M-(S, S, S)-\mathbf{9}$ were successfully synthesized by applying an identical synthetic pathway utilizing the $(S)$ enantiomer of glycidyl nosylate. Interestingly, it was demonstrated that the enantiopure receptors 9 displayed remarkable diastereo- and enantiose- lectivity for the binding of carbohydrate substrates. However, relatively low binding constants were reported (around $\left.10^{2} \mathrm{M}^{-1}\right)^{21}$

In 2014, Martinez and co-workers also exploited the 'template approach' to build enantiopure hemicryptophanes bearing triamide and tris(2-aminoethyl)amine (TREN) features at their southern part (Scheme 2). Such structures were designed for the enantioselective recognition of cationic species like ephedrine and norephedrine. ${ }^{22}$ The southern part of the triamide-based host $\mathbf{1 2}$ was firstly built from the reaction between nitrilotriacetic acid and three equivalents of enantiopure (S)-4-methoxybenzylamine in the presence of $\mathrm{P}(\mathrm{OPh})_{3}$, yielding the tripodal triamidoamine 10 (Scheme 2). Deprotection of the methoxy group (yielding 11) was followed by reaction with com- 
pound 2 (see Scheme 1) in DMF using $\mathrm{Cs}_{2} \mathrm{CO}_{3}$ as the base to give the desired cyclization precursor 12-p. The diastereomeric mixture of hemicryptophane $P-(R, R, R)-\mathbf{1 2}$ and $M$ $(R, R, R)-\mathbf{1 2}$ was obtained through the formation of its northern CTV by an acid-catalyzed triple macrocyclization in formic acid, which occurred in 35\% yield. Both the $P-(R, R, R)-\mathbf{1 2}$ and $M-(R, R, R)-12$ diastereomers were efficiently separated by preparative achiral TLC. Finally, a diastereomeric mixture of the TREN-based hemicryptophanes $P-(R, R, R)-\mathbf{1 3}$ and $M-(R, R, R)-13$ was obtained upon reduction of the amide functions of 12 using borane dimethyl sulfide (BMS) in THF. Interestingly, in this case, the authors reported an easier separation of the $P-(R, R, R)-\mathbf{1 3}$ and $M-(R, R, R)-\mathbf{1 3}$ diastereomers by simple column chromatography on silica gel. The introduction of triamide and TREN units at the southern part of 12 and 13 was found to positively influence the affinities of these receptors toward the binding of carbohydrates. Indeed, the reported binding constants for $\mathbf{1 2}$ and $\mathbf{1 3}$ were up to ten times stronger than those of the previously described hemicryptophanes 9 (ca. $10^{3}$ and $10^{2} \mathrm{M}^{-1}$, respec- tively). Despite the good diastereoselectivities observed for these supramolecular hosts [for instance, $P-(R, R, R)-\mathbf{1 3}$ preferentially binds Oct $\beta$ Glc with respect to Oct $\beta$ Gal with an important 1:31 diastereoselectivity), they failed at providing significant enantioselectivities.

In 2016, Dutasta and Martinez further extended their synthetic strategy to the synthesis of more sophisticated hemicryptophanes 18, simultaneously displaying three types of chiral elements: ( $i$ ) a helically chiral CTV, (ii) three axially chiral binaphthol linkages, and (iii) three stereogenic carbons on the trialkanol moiety. ${ }^{23}$ The eight different stereoisomers of the cage $\mathbf{1 8}$ were obtained following a fivestep synthetic pathway (Scheme 3). Compound (S)-14 was firstly obtained through the nucleophilic substitution of (S)-BINOL with 2 (see Scheme 1) in the presence of the $\mathrm{K}_{2} \mathrm{CO}_{3}$ as the base in acetone. Its subsequent reaction with $(S)$-glycidyl nosylate in DMF provided the epoxide $(S, S)-\mathbf{1 5}$, which was then reacted with an excess of ammonia in methanol leading to the formation of the primary amine $(S, S)$-16. Two equivalents of compound $(S, S)$-15 were then

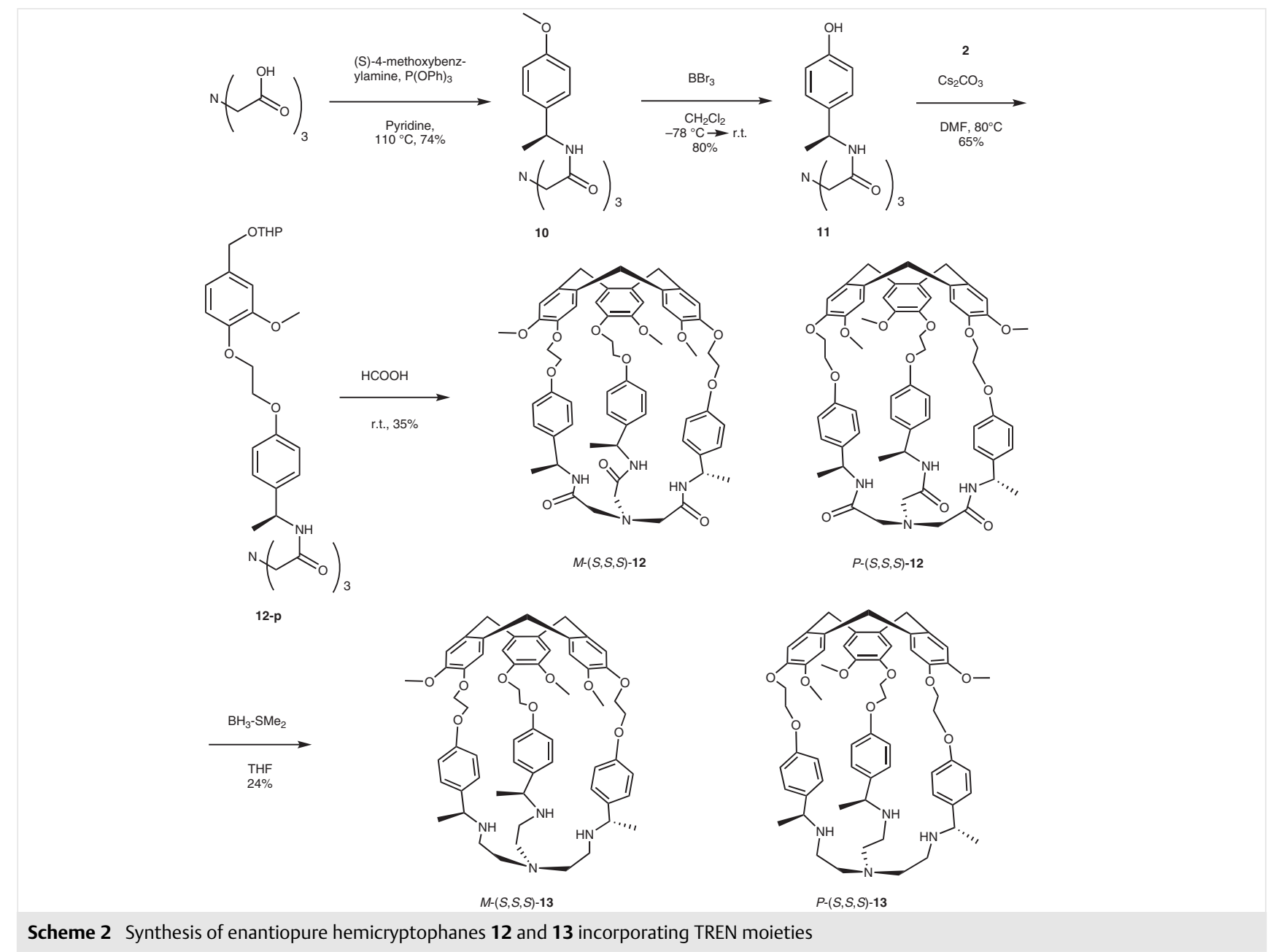



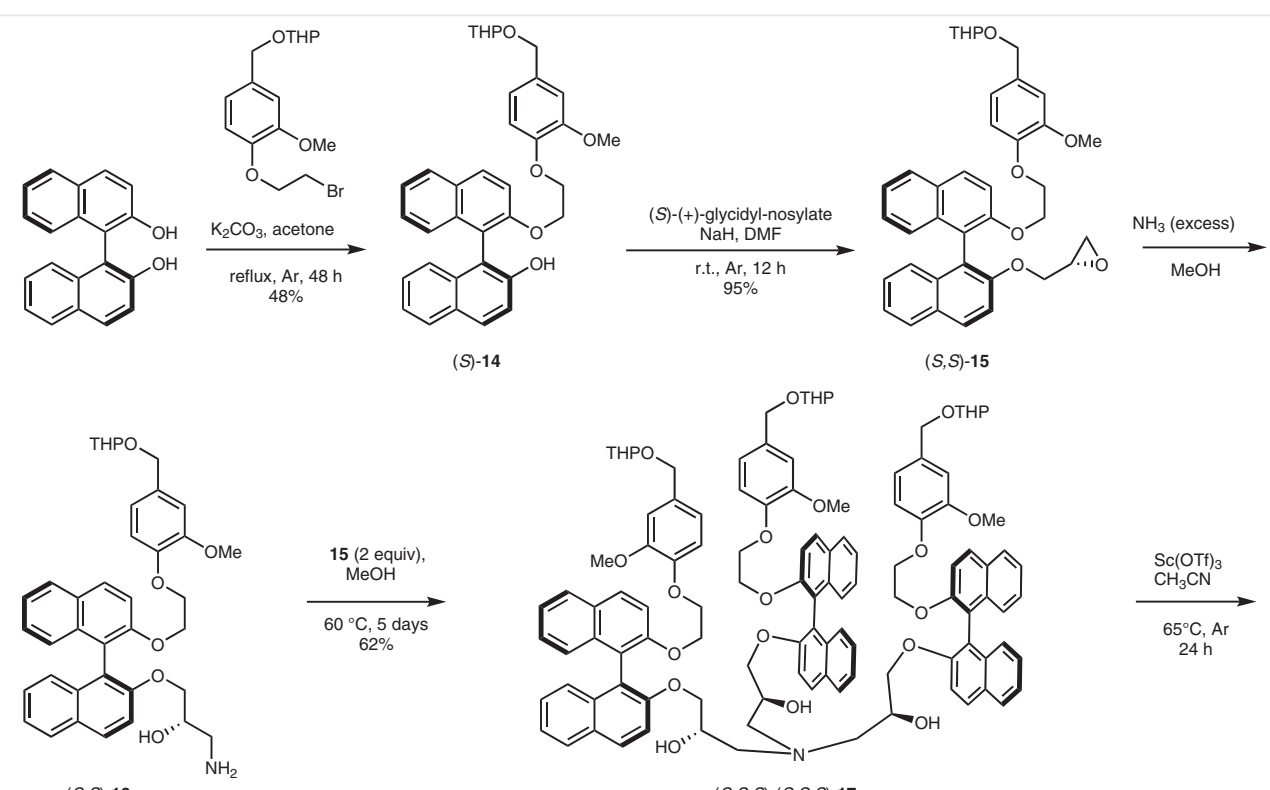

S)-16

$(S, S, S)-(S, S, S)-17$
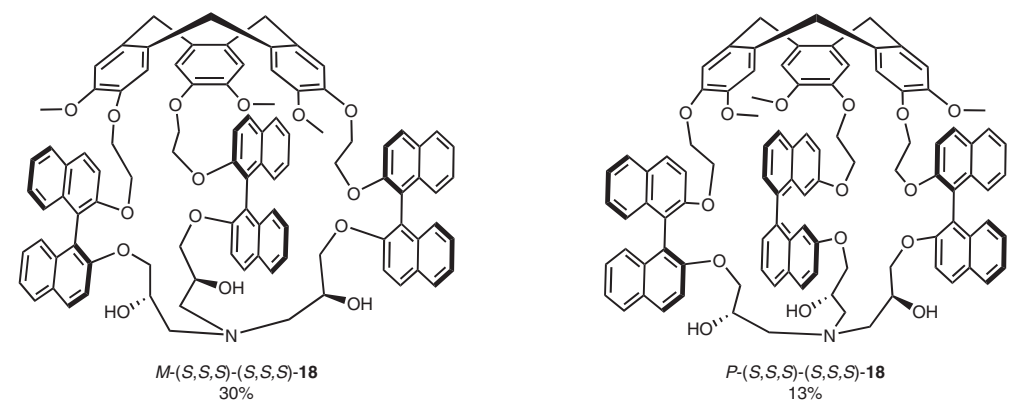

Scheme 3 Synthesis of enantiopure hemicryptophanes 18, incorporating binaphthyl moieties, through intramolecular macrocyclization reactions
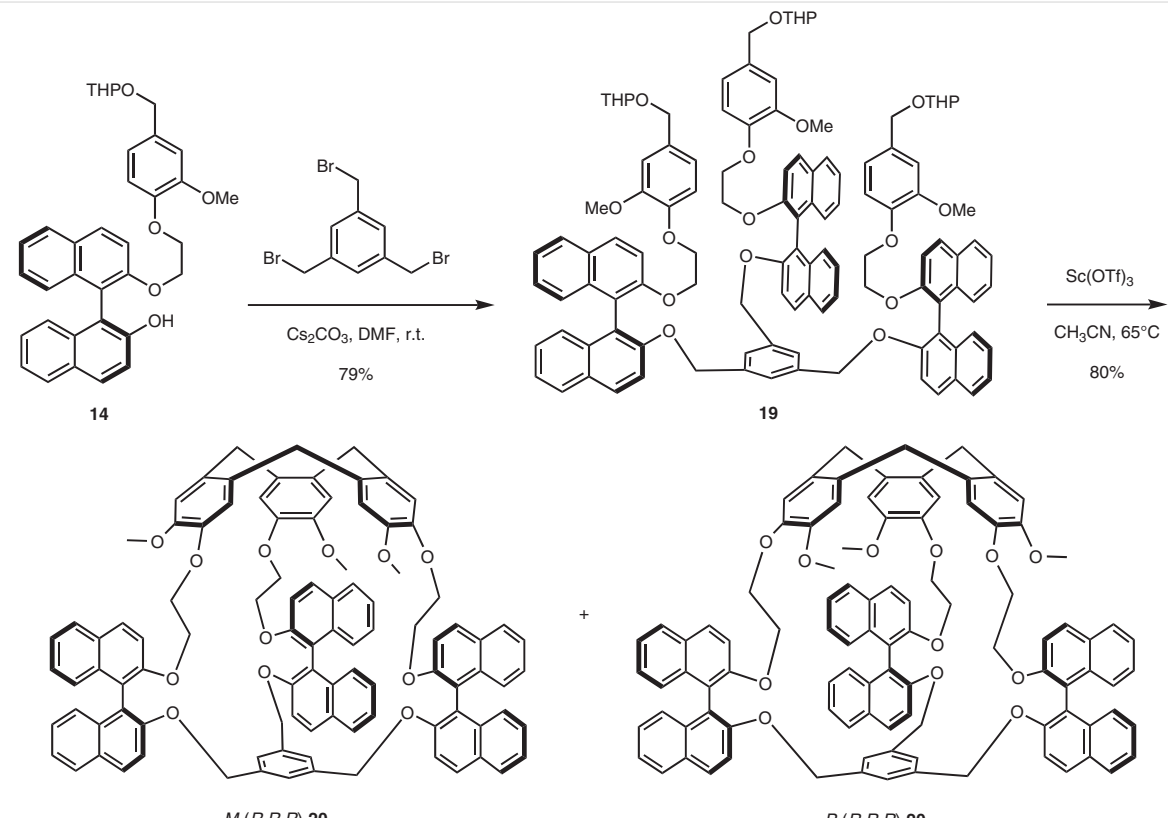

icryptophanes 20 based on a benzenic platform 
connected with $(S, S)$-16 to afford the precursor $(S, S, S)$ $(S, S, S)-\mathbf{1 7}$ in an overall yield of $28 \%$. Finally, the two diastereoisomers $P-(S, S, S)-(S, S, S)-\mathbf{1 8}$ and $M-(S, S, S)-(S, S, S)-\mathbf{1 8}$ were obtained in moderate yields through the treatment of $(S, S, S)-(S, S, S)-17$ with $\mathrm{Sc}(\mathrm{OTf})_{3}$ in $\mathrm{CH}_{3} \mathrm{CN}$ leading to CTV formation by intramolecular cyclization. The other three stereoisomer pairs $[P-(R, R, R)-(R, R, R)-\mathbf{1 8} / M-(R, R, R)-(R, R, R)-\mathbf{1 8}$, $P-(S, S, S)-(R, R, R)-\mathbf{1 8} / M-(S, S, S)-(R, R, R)-18$ and $P-(R, R, R)-$ $(S, S, S)-\mathbf{1 8} / M-(R, R, R)-(S, S, S)-\mathbf{1 8}$ ] were obtained by using the appropriate enantiopure BINOL and glycidyl nosylate starting materials. ECD analysis of the different stereoisomers of 18 revealed overlapped signals for the CTV and binaphthyl groups, precluding the assignment of their absolute configuration by the method described by Collet et al. ${ }^{19 b}$ However, the authors overcame this issue by developing a chemical correlation method. Each enantiopure molecule was synthesized through the [1+1] coupling of enantiopure north and south parts (see Section 3.2, Scheme 14). Absolute configurations were then determined by comparison with these authentic cages. Once engaged in the recognition of carbohydrates (glucose and mannose derivatives), these new enantiopure cages revealed interesting stereoselective recognition events. It was indeed shown that only the $M$ $(S, S, S)-(R, R, R)$ and the $P-(R, R, R)-(S, S, S)$ stereoisomers of $\mathbf{1 8}$ were able to bind glucose derivatives, attesting to remarkable diastereoselective interactions. ${ }^{22}$ Good enantioselectivity towards the anomer Oct $\beta$ Glc was also observed with binding constants six times higher for $P-(R, R, R)-(S, S, S)-\mathbf{1 8}$ than for $M-(S, S, S)-(R, R, R)-\mathbf{1 8}$ (association constants of 537 $\mathrm{M}^{-1}$ and $83 \mathrm{M}^{-1}$ respectively in $\mathrm{CDCl}_{3}$ ).

The same authors further explored a similar synthetic pathway, based on the derivatization of the intermediate 14, in order to build new hemicryptophane structures based on a tripodal benzenic platform (Scheme 4). ${ }^{24}$ The chiral BINOL linkers found in the capsules $\mathbf{2 0}$ allowed for the convenient separation of the $P-(R, R, R)-\mathbf{2 0}$ and $P-(R, R, R)-$ 20 isomers by simple column chromatography. ${ }^{24}$

The precursor 19 was obtained through the nucleophilic substitution of $\mathbf{1 4}$ with tris(bromomethyl)benzene in DMF using $\mathrm{Cs}_{2} \mathrm{CO}_{3}$ as the base. The cyclization step was performed in $\mathrm{CH}_{3} \mathrm{CN}$ with $\mathrm{Sc}(\mathrm{OTf})_{3}$ as the catalyst, giving one pair of diastereomers, $P-(R, R, R)-\mathbf{2 0}$ and $M-(R, R, R)-\mathbf{2 0}$, with a moderate diastereoselectivity (1:1.3 ratio). Recognition toward carbohydrates was investigated showing that binding constants of up to $458 \mathrm{M}^{-1}$ were possible and that exclusive enantioselectivity and diastereoselectivity could be reached.

Enantiopure hemicryptophanes based on bio-relevant macrocyclic chiral platforms have also attracted attention due to their potential applications as bio-inspired receptors. Such cages are indeed merging the CTV recognition properties with those of the macrocyclic unit.

Hutton and co-workers reported an enantiopure hemicryptophane containing a cyclic peptide. ${ }^{25}$ This system was built from the alkylation of the cyclic peptide $\mathbf{2 1}$ with bro-

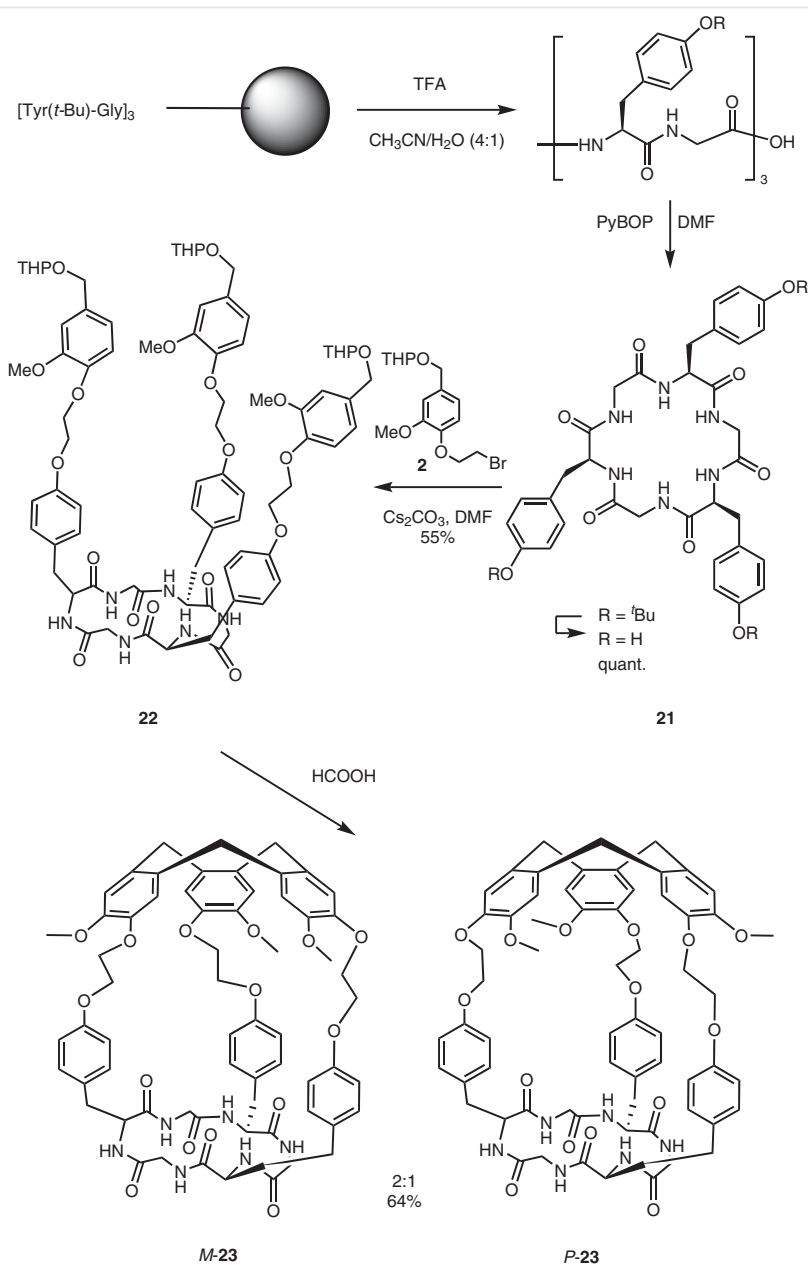

Scheme 5 Synthesis of enantiopure hemicryptophanes incorporating a cyclic peptide

moethyl vanillyl alcohol $\mathbf{2}$ which yielded the precursor 22 (Scheme 5). The northern CTV was then generated by treatment of the precursor with formic acid leading to the racemate of cage $\mathbf{2 3}$ with an overall yield of $35 \%$. The two diastereomers, formed in a 2:1 mixture, were successfully purified by column chromatography. The cyclic peptide 21, made of six residues (tyrosine and glycine alternatively), was previously prepared by cyclization (ByBOP, $1 \mathrm{~h}$, quantitative yield) of the corresponding linear peptide, which was synthesized on a solid support (2-chlorotrityl resin) and cleaved with 5\% TFA. Recognition towards the biologically relevant zwitterion carnitine was investigated and the hemicryptophanes $\mathbf{2 3}$ showed modest chiral discrimination behavior: using $P$-23 as the receptor, a binding constant 1.5 times higher for $R$-carnitine than for $S$-carnitine was found ( $K_{\mathrm{a}}$ of $4.1 \cdot 10^{3}$ and $2.7 \cdot 10^{3} \mathrm{M}^{-1}$ respectively in acetonitrile).

An interesting example of chiral macrocycle-based hemicryptophanes was also reported by Chambron et al. ${ }^{26}$ This system connects one northern CTV to a tripodal per- 

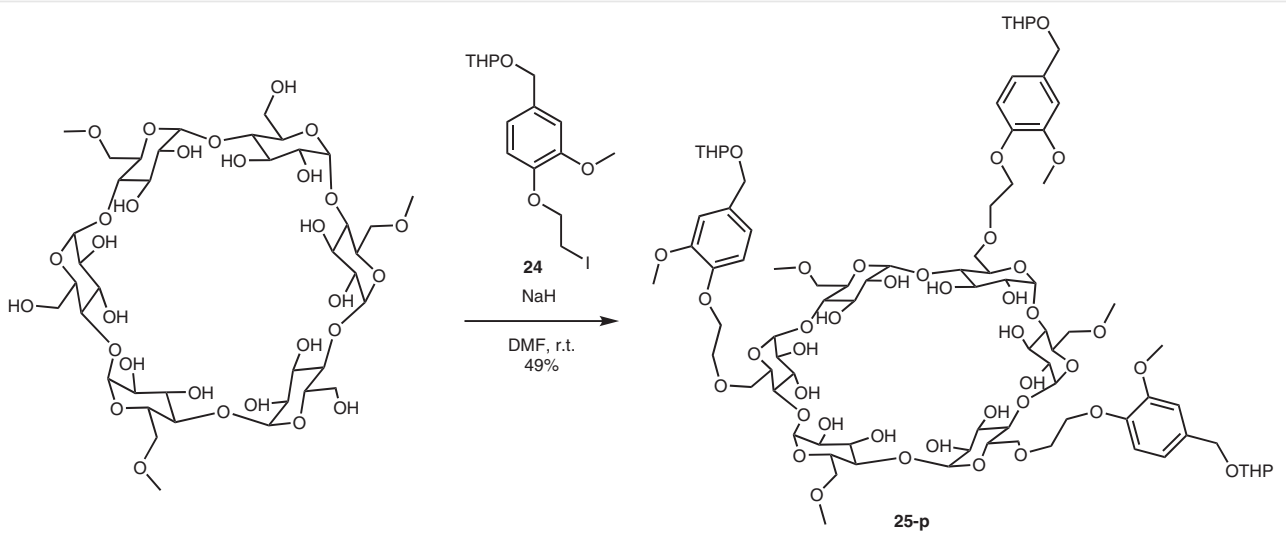

$\mathrm{Sc}(\mathrm{OTf})_{3}, 40^{\circ} \mathrm{C}, 5 \%$
or
$\mathrm{HCOOH}, 55^{\circ} \mathrm{C}, 8 \%$

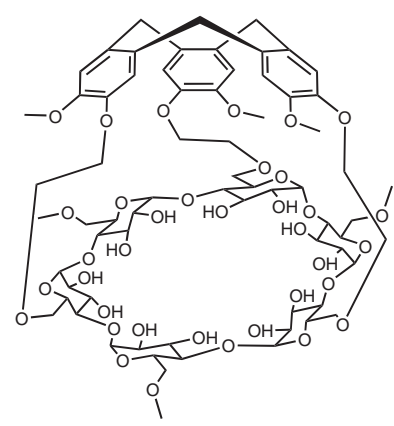

$M-25$

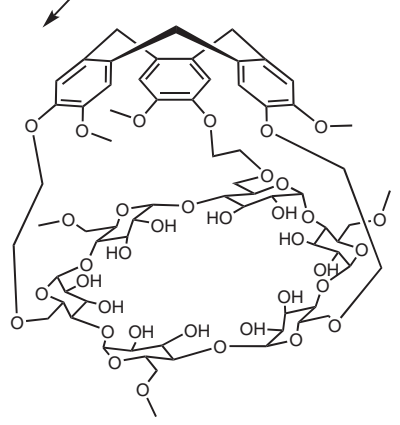

$P-25$

Scheme 6 Synthesis of hemicryptophanes incorporating a cyclodextrin platform

methylated $\alpha$-cyclodextrin feature, aiming at providing a pair of diastereomers. The hemicryptophane precursor 25p was easily obtained in one synthetic step ( $49 \%$ yield) by the alkylation of the starting cyclodextrin with compound 24 in the presence of an excess of sodium hydride in DMF (Scheme 6). However, the final hemicryptophane closure reaction, through intramolecular cyclization, affords a diastereomeric mixture of cages $\mathbf{2 5}$ in very low yields. Indeed, formic acid and $\mathrm{Sc}(\mathrm{OTf})_{3}$-promoted cyclizations resulted in $8 \%$ and 5\% yield, respectively. The $M$ and $P$ diastereomers were formed in a 6:1 ratio and the authors were able to isolate the major diastereomer in pure form.

\section{$2.2[1+1]$ Coupling of the CTV and the Southern Part}

The [1+1] coupling reaction between a CTV racemate and another chiral enantiomerically pure tripodal unit has been also investigated as an alternative strategy to construct optically pure hemicryptophanes.

In 2015, Martinez, Dutasta and co-workers proposed that the thermodynamic resolution of a CTV racemic mixture by coupling with an enantiopure southern unit might represent a straightforward access to enantiopure hemi- cryptophanes, avoiding tedious separation of diastereomers. ${ }^{27}$ The authors demonstrated the feasibility of the approach through the construction of three capsules following a $[1+1]$ approach. Three reductive amination reactions between the aldehyde-based CTV $\mathbf{2 6}$ and three enantiopure TREN derivatives, $(S, S, S)$-TREN- $\mathbf{R}_{\mathbf{3}}$, were conducted (Scheme $7)$. In all cases, the exclusive formation of the $M-(S, S, S)$ diastereomers of hemicryptophanes 27 (15-22\% yield) were

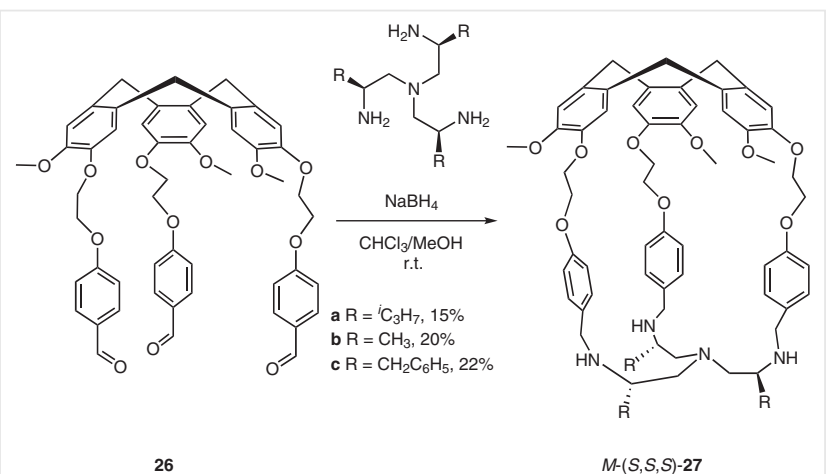

Scheme 7 Synthesis of enantiopure hemicryptophanes through a thermodynamic chiral resolution of a CTV racemic mixture 
observed, independently of the nature of the TREN substituents. This behavior was explained by two different kinds of reaction between the TREN unit and the two enantiomers of CTV 26. It was observed that reaction with $M-\mathbf{2 6}$ led to the formation of well-defined and soluble cages $M$ $(S, S, S)-\mathbf{2 7}$, while the reaction with $P$-26 gave only insoluble polymeric species.

In 2013, Chambron et al. further extended their work on macrocycle-based hemicryptophanes by connecting a CTV unit with a tripodal cyclodextrin through a triple disulfidebridge feature (Scheme 8$){ }^{28}$
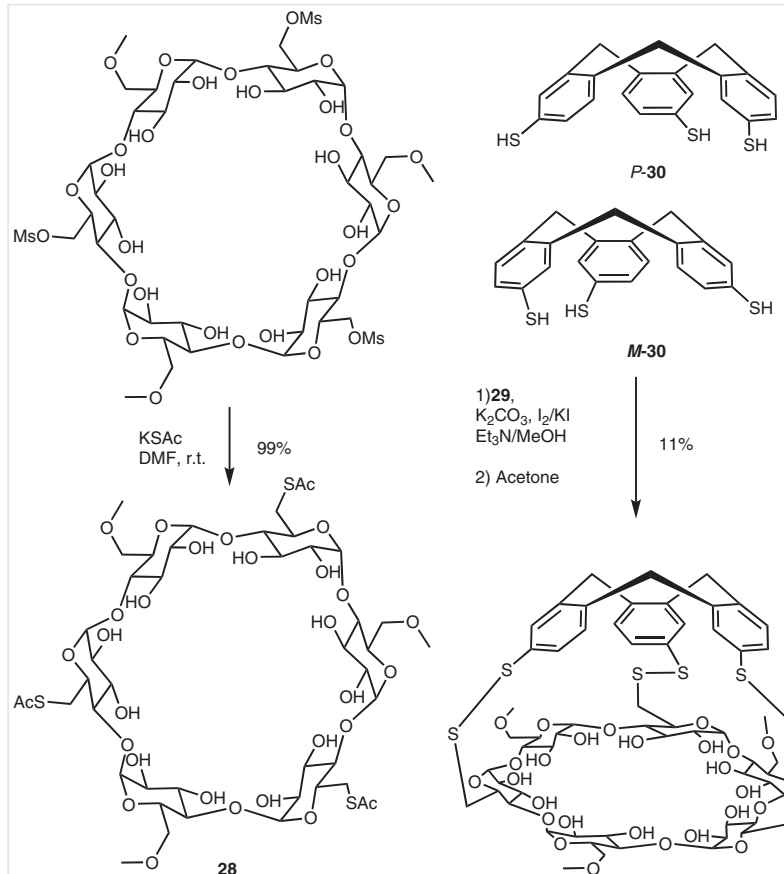

$P-30$
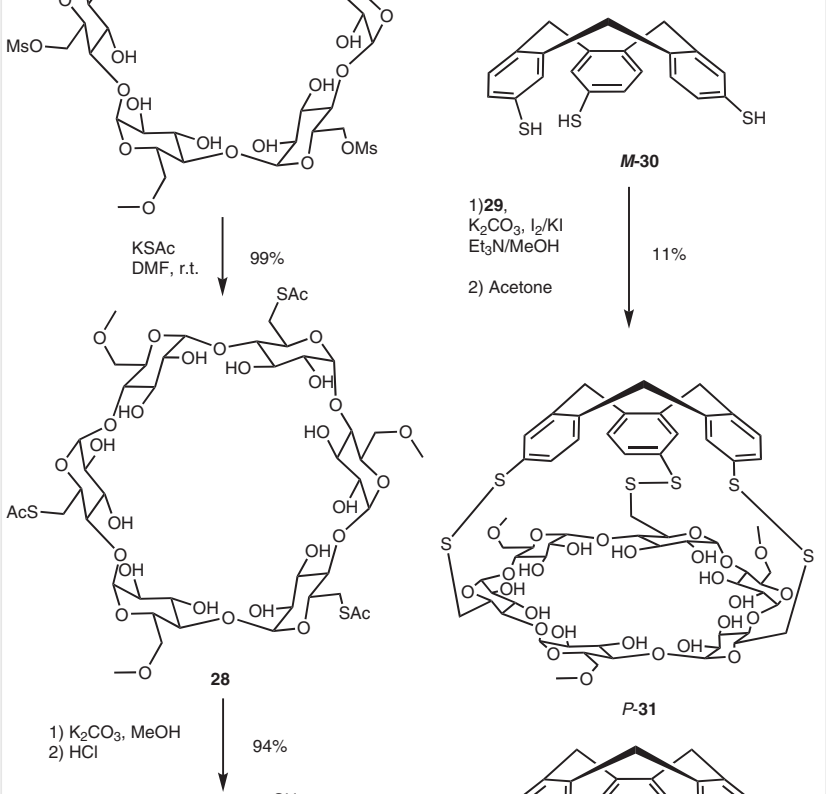

$P-31$
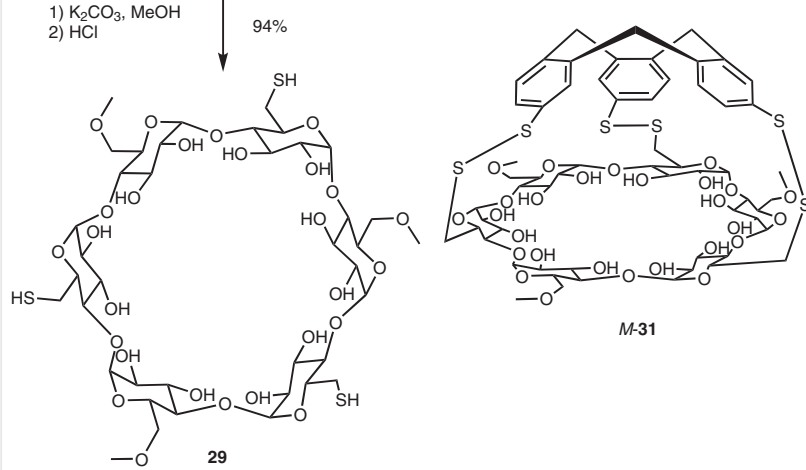

Scheme 8 Coupling of a CTV unit and a cyclodextrin containing sulfide functions

The racemic mixture of the triply bridged hemicryptophane 31 was obtained in 11\% yield through the intermolecular formation of disulfide bonds between the cyclodextrin 29 and the racemate of CTV $\mathbf{3 0}$, which both display three thiol substituents. Synthesis of the desired trisubsti- tuted $\alpha$-cyclodextrin $\mathbf{2 9}$ was achieved through the methanolysis of the three thioester substituents of the cyclodextrin 28 in the presence of $\mathrm{K}_{2} \mathrm{CO}_{3}$. The final coupling step between 29 and $\mathbf{3 0}$ was performed by the addition of a solution of $\mathrm{I}_{2}$ in $\mathrm{MeOH}$ to a methanolic solution of the two partners, yielding the $M$ and $P$ diastereomers of $\mathbf{3 1}$ as a 5:3 mixture. It was therefore demonstrated that the thermodynamic equilibrium, which controls the disulfide bridge formation, favors the formation of the $M$ diastereoisomer over the $P$ diastereoisomer. However, despite this promising selectivity, the two diastereomers were not successfully separated.

\section{Enantiopure Hemicryptophanes Obtained by Means of Chiral HPLC Resolution of Enan- tiomers}

The use of the chiral semi-preparative high-performance liquid chromatography (HPLC) technique for the resolution of racemic mixtures is part of the few approaches that can be followed to synthesize highly enantiopure hemicryptophanes. Following this HPLC-based strategy, enantiopure covalent cages can be obtained by $(i)$ resolution of the final hemicryptophane racemate, or (ii) building of the cage from a resolved mixture of CTV-based precursors. In this section we will provide examples of versatile optically pure hemicryptophane structures, which can be obtained following the HPLC purification method, as well as a brief description of their putative applications in supramolecular recognition and catalysis.

\subsection{Resolution of Hemicryptophane Racemates}

In 2010, Martinez, Dutasta and co-workers reported the first example of the resolution of a racemic mixture of hemicryptophane molecular cages using the chiral semipreparative HPLC purification technique. ${ }^{29}$ They demonstrated the feasibility of $(i)$ the isolation of both $P$ - and $M$ enantiomers of hemicryptophane $\mathbf{3 2}$ through successive injections $\left(8.0 \mathrm{mg} / \mathrm{mL}\right.$ solutions in $\left.\mathrm{CDCl}_{3}\right)$ of the racemic mixture on a (S,S) Whelk-O1 chiral column, and (ii) the assignment of their absolute configuration. The study of the circular dichroism (CD) of the first [(+)-32] and second eluted [(-)-32] enantiomers allowed the authors to assign (+)-32 to the $P$-stereomer and (-)-32 to the $M$-stereomer. Excellent enantiomeric excesses of $>99 \%$ and $>96 \%$ for the first eluted $P$ - and the second eluted $M$-enantiomer were observed. It should be noted that the racemic mixture of $\mathbf{3 2}$ was obtained following an identical pathway to that described in Scheme 2, but using methylbenzylamine instead of $(S / R)-4$ methoxy- $\alpha$-benzylamine. The ability of the (+)- and (-)-stereoisomers of $\mathbf{3 2}$ to act as hosts for carbohydrate derivatives was further studied by ${ }^{1} \mathrm{H}$ NMR titration experiments. Specific recognitions of $\alpha$ - and $\beta$-anomers of $D$-glucose deriva- 
tives were interestingly observed. ${ }^{21}$ However, this good enantioselectivity was associated with relatively weak association constants (typically below $10^{2} \mathrm{M}^{-1}$ ). Furthermore, it should be noted that $(i)$ the resolved hemicryptophane enantiomers were only obtained on milligram scale, and (ii) the chiral HPLC technique was found to be highly sensitive to structural modifications of the capsules. This purification technique indeed failed at purifying a racemic mixture of the previously reported hemicryptophane $33^{30}$ bearing a TREN moiety in its southern part (Scheme 9, a). Therefore, only small changes in the structure of a hemicryptophane can strongly impact the effectiveness of its optical resolution. However, chiral HPLC was reported as an effective tool for the resolution of one derivative of $\mathbf{3 3}$ incorporating an azaphosphatrane moiety in its southern part: $\mathbf{P H}^{+} @ 33$ (Scheme 9, b). ${ }^{31}$

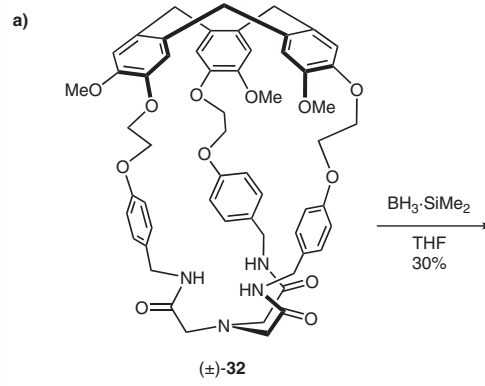

Chiral HPLC optical resolution $\checkmark$

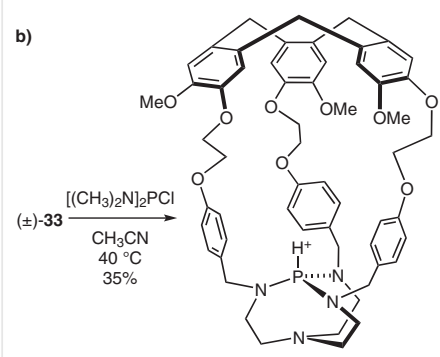

$\mathrm{PH}^{+} @( \pm)-33$

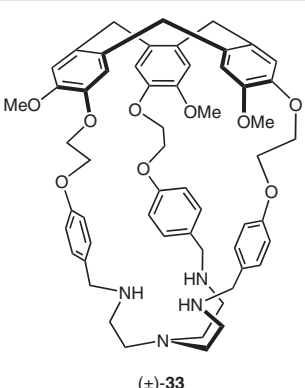

$( \pm)-33$

Chiral HPLC optical resolution $*$

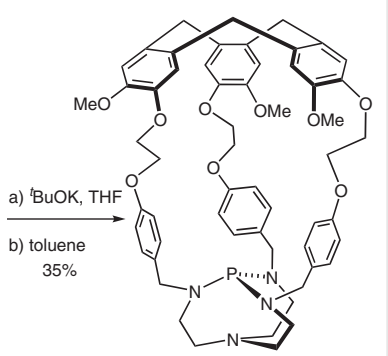

$\mathbf{P} @( \pm)-33$
Chiral HPLC optical resolution $\checkmark$

Scheme 9 (a) Synthesis of hemicryptophane 33 starting from 32. (b) Preparation of the encaged azaphosphatrane $\mathbf{P H}^{+} @ 33$

Since these initial reports, substantial progress has been made by the group of Martinez regarding resolution of hemicryptophane racemic mixtures. They exploited the chiral HPLC tool to obtain the enantiopure cages $(M)-34$, $(P)-34,(M)-35$ and $(P)-35$, containing a tris(2-pyridylmethyl)amine (TPA) moiety at their southern parts, on a preparative scale of close to hundreds of milligrams (Scheme 10). ${ }^{32}$ The hemicryptophane racemates $\mathbf{3 4}$ and $\mathbf{3 5}$, respectively bearing naphthyl- and phenyl linkers, have both been obtained in a fourteen-step synthesis on gram scale. These two supramolecular cages were able to coordinate a $\mathrm{Zn}$ (II) metal cation at their southern TPA unit (Scheme 10). Both cages were prepared starting from the TPA-trichloride precursor $\mathrm{TPACl}_{3}$, which was obtained in a seven-step synthetic procedure (Scheme 11) with an overall yield of $45 \%$. The precursors 34-p and 35-p were prepared from the condensation between $\mathrm{TPACl}_{3}$ and the naphthyl and phenyl intermediates 34-i and 35-i, respectively (Scheme 10). Closure of the hemicryptophane $\mathbf{3 5}$ was achieved through the final building of its northern CTV unit following a triple macrocyclization reaction in formic acid (Scheme 10, b). The authors explained the remarkable effectiveness of this cageclosing reaction ( $90 \%$ yield, isolated by precipitation) by the putative protonation of the TPA unit leading to a pre-organized cyclization precursor. In the case of $\mathbf{3 4}$, the triple macrocyclization closing reaction was performed in the presence of the Lewis acid $\mathrm{Sc}(\mathrm{OTf})_{3}$ in $\mathrm{CH}_{3} \mathrm{CN}$, rather than in formic acid, due to the formation of several undesired products in the latter case.

Remarkably, the racemic mixtures of both hemicryptophanes 34 and 35 were successfully resolved by chiral HPLC, representing the first example of enantiopure TPAbased molecular capsules. The $M$ - and $P$-stereoisomers of 34 and 35 were effectively separated on a Chiralpak ID column on preparative scales of $80 \mathrm{mg}$ and $50 \mathrm{mg}$ of each enantiomer with ee values $>99 \%$ in, respectively, 12 and 3 hours. The absolute configurations of each enantiopure hemicryptophane (+)-34, (-)-34, (+)-35 and (-)-35 were determined by comparison of their ECD spectra with previously characterized optically pure CTV-based structures. ${ }^{22,25,29,33}$ The authors finally demonstrated the ability of the heteroditopic $\mathrm{Zn}$ (II) hemicryptophane complex $\mathbf{Z n -}$ 35 (Scheme 10) to act as a supramolecular receptor for zwitterionic guests. Despite these promising synthetic and binding results, to date, studies of these optically pure TPAbased hosts for stereo- and enantioselective encapsulations have not been reported.

In connection with their previous studies on the stereoselective recognition of carbohydrates, ${ }^{21,22}$ in 2018, Martinez, Dutasta and co-workers reported new advances towards selective guest recognition dictated by the inner helical chirality of the CTV unit. These researchers designed the first optically pure ( $M$ - and $P$-) hemicryptophane hosts simultaneously displaying enantioselectivities in recognition and strong binding constants towards carbohydrate guests. $^{34}$ The racemic mixture of the cage $\mathbf{3 7}$ was obtained in four steps starting from the previously reported $\mathrm{CTV}\left(\mathrm{CH}_{2} \mathrm{CH}_{2} \mathrm{Br}\right)_{3}$ precursor. ${ }^{35} \mathrm{CTV}\left(\mathrm{CH}_{2} \mathrm{CH}_{2} \mathrm{Br}\right)_{3}$ was firstly derivatized into the $\mathrm{CTV}\left(\mathrm{CH}_{2} \mathrm{CH}_{2} \mathrm{NH}_{2}\right)_{3}$ intermediate (Scheme 12); 37 was then obtained in a $42 \%$ yield through a [1+1] coupling cage-closing reductive amination with the $C_{3}$ derivative $\mathbf{3 6}$.

The (-)- $M$ and (+)-P stereoisomers of $\mathbf{3 7}$ were efficiently discriminated by chiral HPLC. Separation on a semi-preparative Chiralpak ID column [EtOH and $\mathrm{Et}_{3} \mathrm{~N} / \mathrm{CH}_{2} \mathrm{Cl}_{2}$ (50:50) eluent] led to the isolation of both enantiomers with ee values $>98.5 \%$. It was demonstrated through recognition stud- 


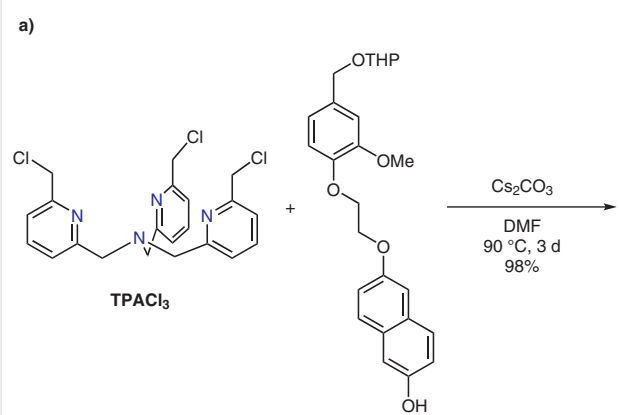

34- $\mathrm{i}$

b)

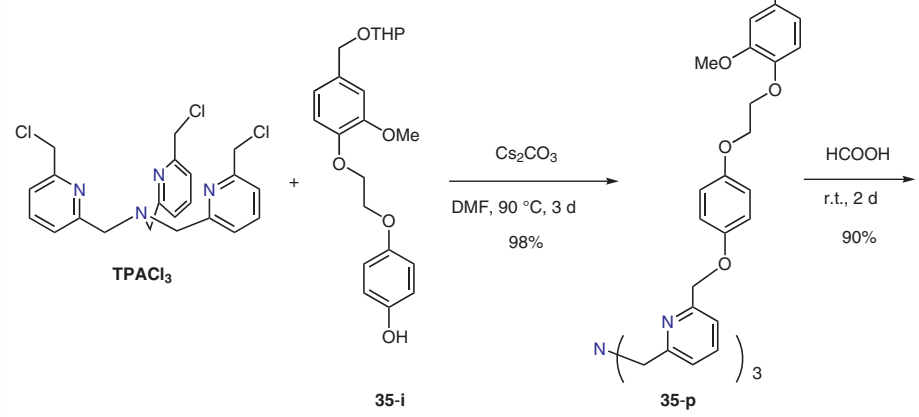

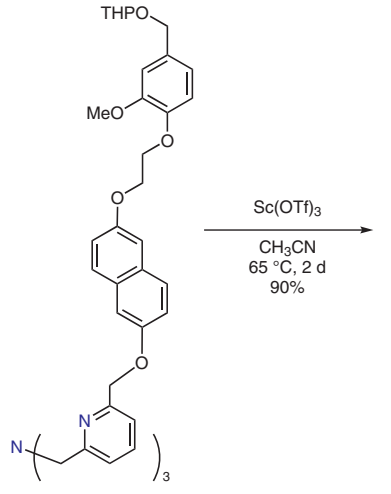

34-p

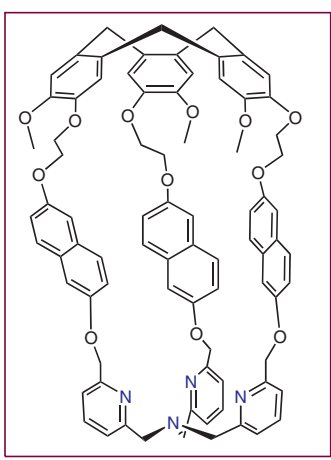

$( \pm)-34$
Chiral HPLC

Fast and facile optical resolution

$-50-80 \mathrm{mg}$ of each enantiomer

Scheme 10 Synthesis of the racemic mixtures of hemicryptophanes $\mathbf{3 4}$ and $\mathbf{3 5}$

ies of six carbohydrate stereoisomers that the $P$ - and $M$-stereoisomers of the host $\mathbf{3 7}$ display remarkable enantioselectivities [exclusive for galactose derivatives which are only recognized by $M-37$ (Figure 3)], together with relatively high binding constants $\left(K_{\mathrm{a}}>10^{3} \mathrm{M}^{-1}\right.$ in some cases). This switch in substrate recognition properties, depending on the enantiomer of the host, represents a new strategy for the fine-tuning of hemicryptophane hosts in order to selectively recognize the targeted sugar derivative.

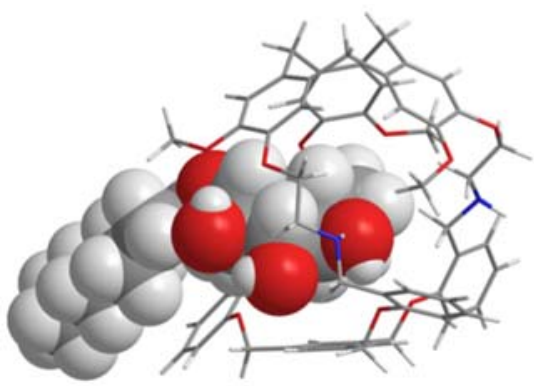

Figure 3 DFT-optimized structure of Oct-B-Glc@M-37
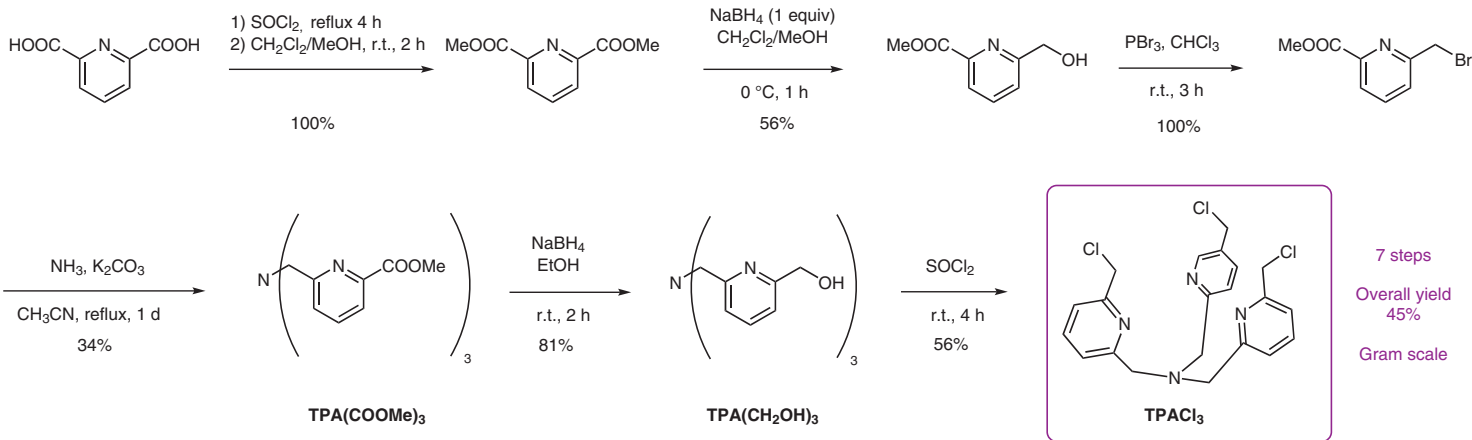

Scheme 11 Synthesis of the precursor $\mathrm{TPACl}_{3}$ 

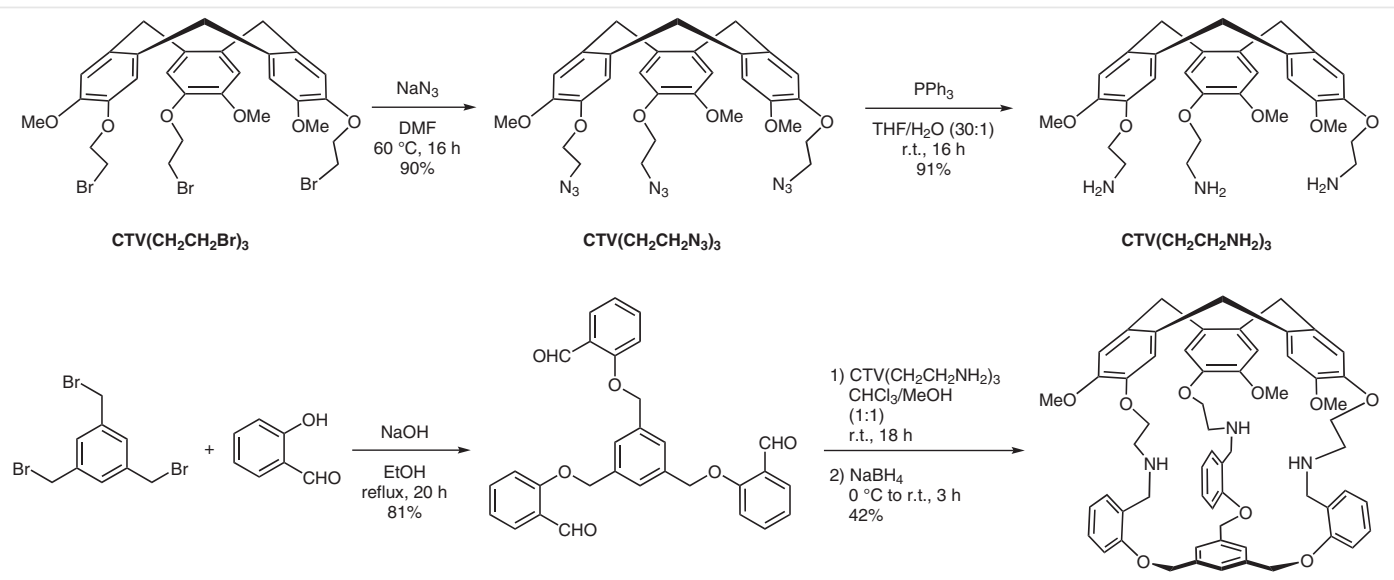

36

$( \pm)-37$

Scheme 12 Synthesis of hemicryptophane 37 (racemic)

\subsection{Resolution of CTV-Based Precursor Racemates}

As reported in the previous section, optical resolution of the racemic mixture of a desired hemicryptophane, by means of semi-preparative chiral HPLC, is a highly valuable qualitative method to obtain optically pure organic architectures. However, this strategy suffers from two major drawbacks: $(i)$ the efficiency of the chiral HPLC separation which is highly sensitive to the structure of the desired capsules, and (ii) the amounts of isolated products which are sometimes low (milligram scale) even when the synthesis of the racemic mixture is performed on gram scale. ${ }^{32}$ Therefore, the development of new and easily accessible strategies for the preparation and purification of versatile enantiopure hemicryptophanes, on a relatively large scale, is of particular importance. For a variety of applications ranging from sensing, delivering and transportation to synthesis and catalysis in confined spaces, being able to rapidly build versatile nanocages on gram scale is indeed critical. With such consideration in mind, Martinez, Vanthuyne and coworkers have been working on a novel approach based on the optical resolution of one CTV-based key intermediate on a relatively large scale prior to building the desired hemicryptophane cages. ${ }^{36}$ Following this strategy, new optically pure hemicryptophanes could be obtained in three steps starting from the racemic mixture of the key intermediate by: (1) optical resolution, (2) synthetic derivatization, and (3) a cage-closing reaction (Scheme 13). To be regarded as reliable, such an approach, based on the derivatization of an enantiopure CTV intermediate, must respect some basic requirements: $(i)$ a rapid and straightforward preparation of each enantiomer of the key precursor on gram scale, (ii) the synthetic derivatizations and cage-closing reactions must be accessible under mild conditions to avoid racemization of the CTV unit, and (iii) the preservation of the enantiopurity must be easily checked during all steps of the synthetic process. The quest for such key intermediates led to success in 2016 with the preparation of 2 grams of each of the $M$ - and $P$-enantiomers of the precursor $\mathrm{CTV}\left(\mathrm{CH}_{2} \mathrm{CH}_{2} \mathrm{Br}\right)_{3}$ (Scheme 13), with an enantiomeric excess $>99.5 \%$ by means of preparative chiral HPLC. A study of the energy barrier for the interconversion process of $\mathrm{CTV}\left(\mathrm{CH}_{2} \mathrm{CH}_{2} \mathrm{Br}\right)_{3}$ was performed revealing a negligible dependence on the solvent polarity, and a much stronger temperature dependence. Half-life times for each enantiomer of $\mathrm{CTV}\left(\mathrm{CH}_{2} \mathrm{CH}_{2} \mathrm{Br}\right)_{3}$ is 5 months at $25^{\circ} \mathrm{C}$ and 7 days at $40{ }^{\circ} \mathrm{C}$. The authors therefore claim that steps 2 [derivatization of $\mathrm{CTV}\left(\mathrm{CH}_{2} \mathrm{CH}_{2} \mathrm{Br}\right)_{3}$ ] and 3 (cage-closure reactions) must be performed at room temperature regardless of the nature of the solvent.

This important breakthrough was followed by the gramscale preparation of eight optically pure hemicryptophanes, which were obtained in four steps in reaction times of one week (Figure 4). ${ }^{36}$ In order to decrease the typical reaction temperature for the first derivatization step (nucleophilic substitution between $\mathrm{OH}$ and $\mathrm{Br}$, see Scheme 13, step c), the optimized reaction conditions described the use of $\mathrm{Cs}_{2} \mathrm{CO}_{3}$ as the base in DMF at $298 \mathrm{~K}$ for 48 hours. Under these conditions, the $M$ - and $P$-stereoisomers of the CTV aldehyde precursors (Scheme 13) were easily isolated in $92 \%$ to $98 \%$ yield. The optically pure hemicryptophanes were subsequently obtained by introducing a southern $C_{3}$ TREN unit via a $[1+1]$ reductive amination cage-closing reaction with the CTV aldehyde precursors, under standard conditions (Scheme 13, step d). Finally, the retention of the absolute configuration of all eight isolated hemicryptophanes, compared to their respective enantiopure CTV precursors, was clearly confirmed by measurement of ee values in an elegant ${ }^{1} \mathrm{H}$ NMR study involving D-camphorsulfonic acid as a chiral resolving agent. Importantly, the authors obtained 1.4 grams of the optically pure cage compound $M-33$ in only a one-week period (four steps), highlighting the partic- 


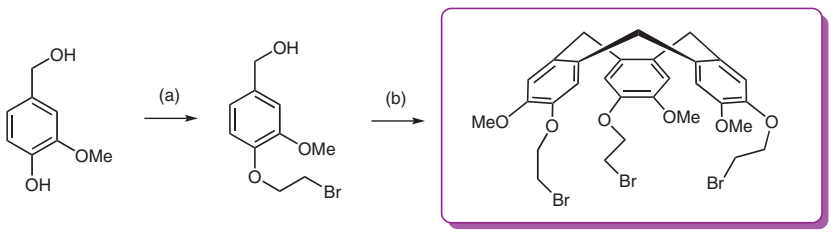

Key CTV intermediaite

- Rapid and facile optical resolution Chiral HPLC)

Gram scale (2 $\mathrm{g}$ of each emantiomer)

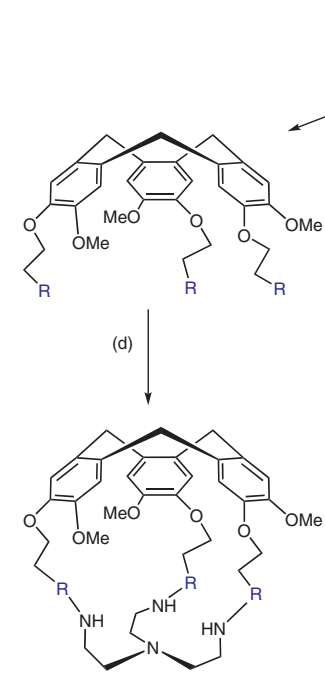

(c) 1. Optical resolution
2. Synthetic derivatization
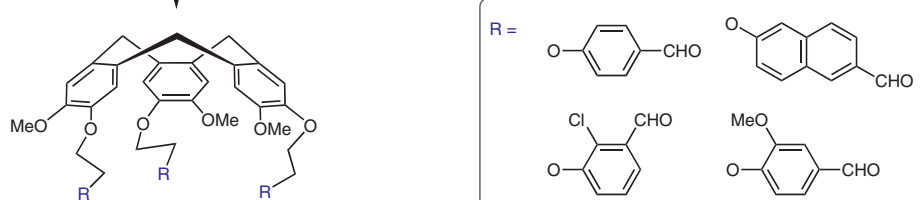

Opticaly pure hemicryptophanes

- 8 examples

- Mild conditions, 4 steps (time = one week)

- Gram scale

Preservation of the enantiopurity

Scheme 13 Representation of the enantiopure hemicryptophane synthetic pathway based on the optical resolution of the key CTV intermediate $\mathrm{CTV}\left(\mathrm{CH}_{2} \mathrm{CH}_{2} \mathrm{Br}\right)_{3}$ : (a) 1,2-dibromoethane, $\mathrm{K}_{2} \mathrm{CO}_{3}$, EtOH, $50{ }^{\circ} \mathrm{C}, 6 \mathrm{~h}, 48 \%$; (b) $\mathrm{Sc}(\mathrm{OTf})_{3}, \mathrm{CH}_{3} \mathrm{CN}$, reflux, $72 \mathrm{~h}, 41 \%$; (c) corresponding hydroxybenzaldehyde (R), $\mathrm{Cs}_{2} \mathrm{CO}_{3}, \mathrm{DMF}, 40{ }^{\circ} \mathrm{C}, 24 \mathrm{~h}, 92-98 \%$; (d) TREN, $\mathrm{CHCl}_{3} / \mathrm{MeOH}, 20^{\circ} \mathrm{C}, 16 \mathrm{~h}$, then $\mathrm{NaBH}_{4}, 20^{\circ} \mathrm{C}, 3 \mathrm{~h}, 37-64 \%$.

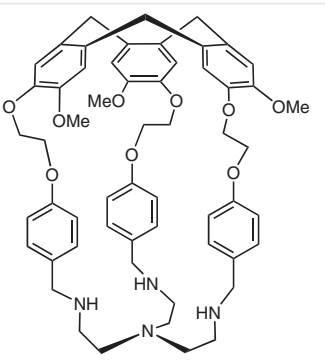

(P)-33

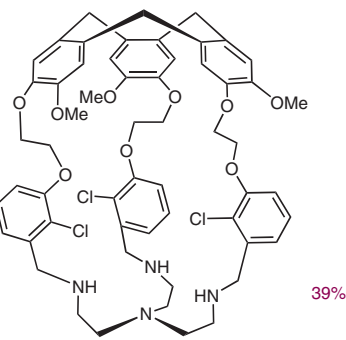

(P)-39

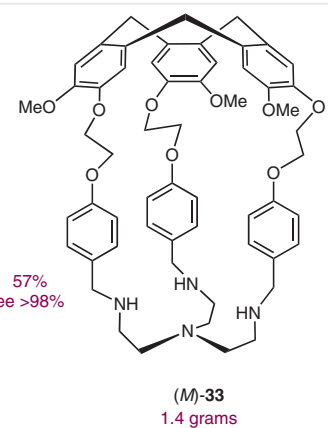

1.4 grams

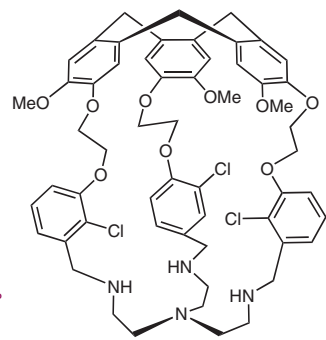

(M)-39

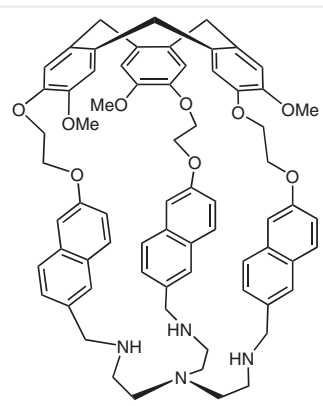

$(P)-38$

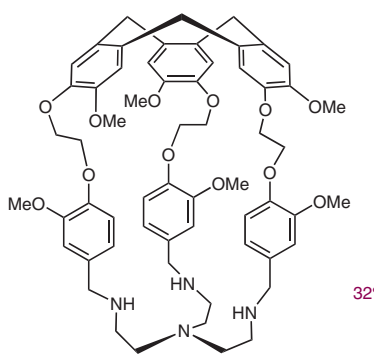

(P)-40

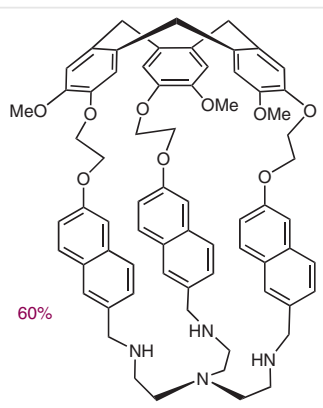

(M)-38

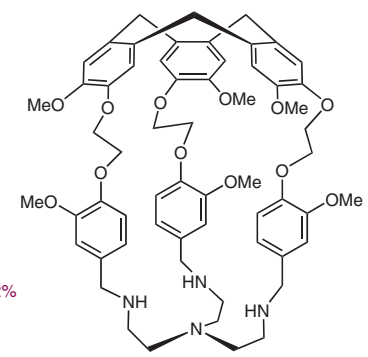

(M)-40

Figure 4 Structures of the eight enantiopure hemicryptophanes obtained starting from optically pure $P$ - and $M-C T V\left(C H_{2} C \mathrm{H}_{2} \mathrm{Br}\right)_{3}$ 


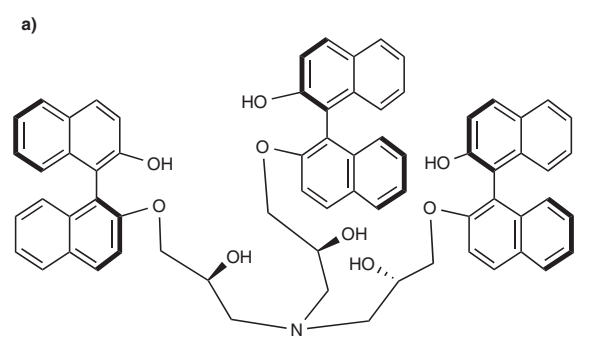

$(S, S, S)-(S, S, S)-41$

b)

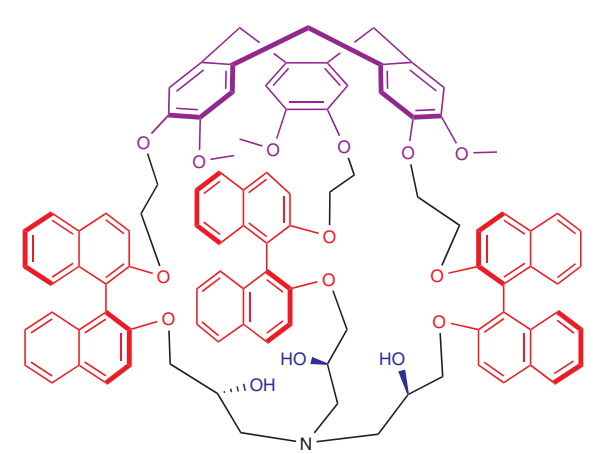

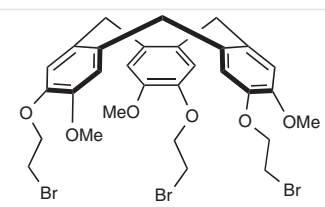

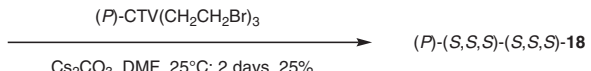

$(P)-(R, R, R)-(R, R, R)-18$

Scheme 14 (a) Synthesis of the hemicryptophane $P-(S, S, S)-(S, S, S)-18$ via a [1+1] closing reaction. (b) Structure of the hemicryptophane $P$ - $(R, R, R)$ $(R, R, R)-18$ displaying three kinds of chirality

ular effectiveness of the approach. Furthermore, it should be noted that the chiral HPLC resolution of the racemic mixture of the same cage $\mathbf{3 3}$ was found to be unsuccessful (see Scheme 9).

Once the concept had been proven, the same group further exemplified the versatility of the approach. Aiming at increasing the level of complexity found in hemicryptophane structures, the cage 18 , possessing three types of stereogenic elements, was designed, synthesized, and successfully isolated..$^{23}$

Starting from the $M$ - and P-enantiomers of $\mathrm{CTV}\left(\mathrm{CH}_{2} \mathrm{CH}_{2} \mathrm{Br}\right)_{3}$, binaphthol and trialkanol chiral units were respectively introduced as linkers and southern moieties of the new architecture. The enantiopure versions of 18 were obtained in $25 \%$ yield by a simple [1+1] macrocyclization reaction between resolved $\mathrm{CTV}\left(\mathrm{CH}_{2} \mathrm{CH}_{2} \mathrm{Br}\right)_{3}$ and enantiopure triphenol (S,S,S)-(S,S,S)-41 (Scheme 14). The resulting cage displays helical, axial and central chirality through its CTV hat (northern part), its three binaphthol walls (linkers) and its trialkanol $C_{3}$ unit (southern part). The $(S)$-binaphthol unit derivatized with a $(S, S, S)$-trialkanol unit $(S, S, S)-(S, S, S)-41$ was previously synthesized in five steps (Scheme 15).

Both $(P)-(S, S, S)-(S, S, S)-\mathbf{1 8}$ and $(M)-(S, S, S)-(S, S, S)-18$ were obtained starting from the $P$ - or $M-\mathrm{CTV}\left(\mathrm{CH}_{2} \mathrm{CH}_{2} \mathrm{Br}\right)_{3}$ isomers. $P$ - and $M-(R, R, R)-(R, R, R)-\mathbf{1 8}$ were prepared starting from $(R, R, R)-(R, R, R)-\mathbf{4 1}$; and finally $(P)-(S, S, S)-(R, R, R)-\mathbf{1 8}$ was achieved using the $(R)-(-)$-glycidyl nosylate precursor to prepare the $(S, S, S)-(R, R, R)-\mathbf{4 1}$ intermediate. The enantio-
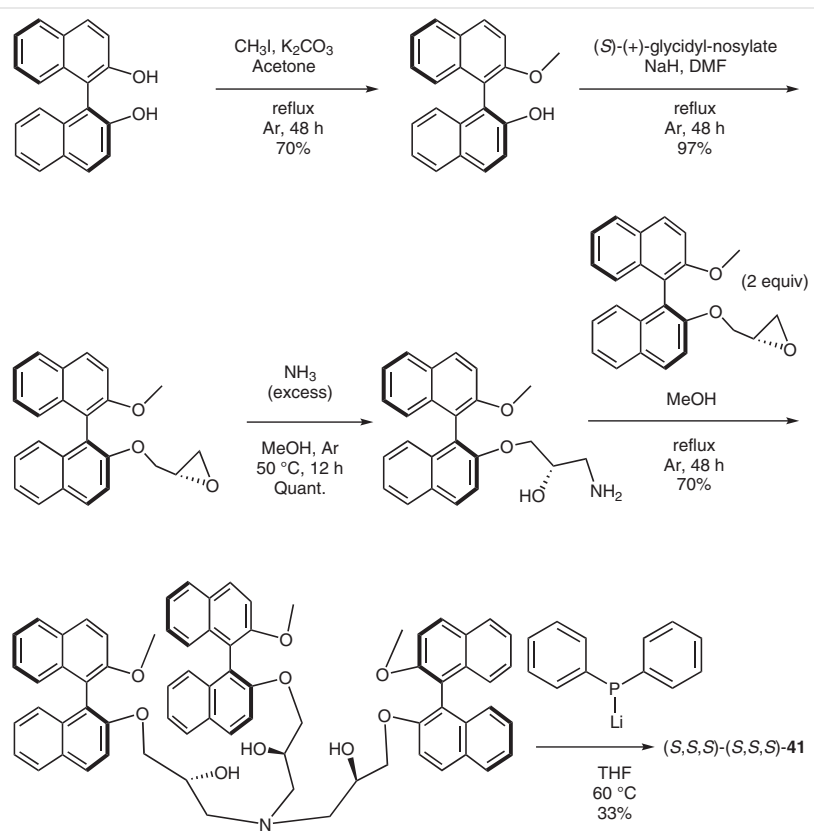

Scheme 15 Synthesis of (S,S,S)-(S,S,S)-41 using the (S)-(+)-glycidyl nosylate 
a)

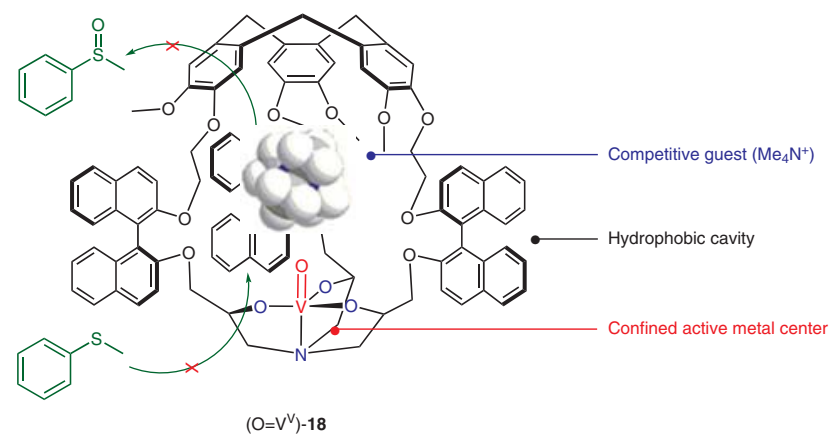

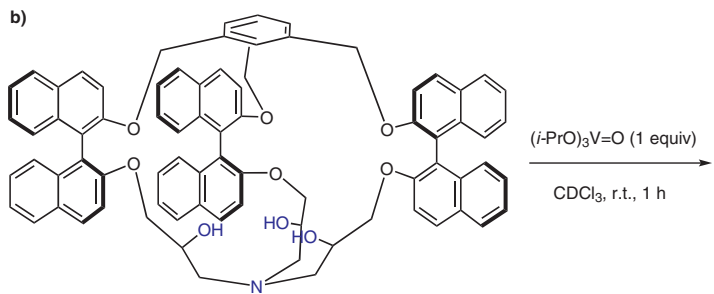

42

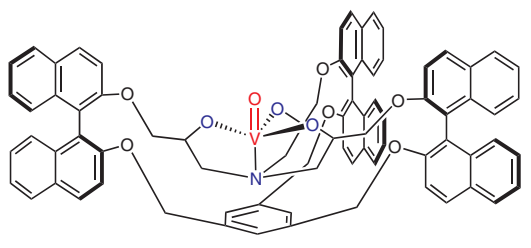

$\left(\mathrm{O}=\mathrm{V}^{\mathrm{V}}\right)-42$

Scheme 16 (a) Structure of the oxidovanadium active center confined inside the hydrophobic cavity of 18, together with the representation of the substrate selectivity (illustrated by the inhibition of the thioanisole oxidation observed when the $\mathrm{Me}_{4} \mathrm{~N}^{+}$competitive guest is bound inside the cavity). (b) Synthesis of the oxidovanadium complex $\left(\mathbf{0}=\mathbf{V}^{\mathrm{V}}\right)-42$

pure version of hemicryptophane $\mathbf{1 8}$ has been recently used as a metal ligand, aiming at introducing a metal-based active center in a controlled chiral environment. The oxidovanadium complexes based on the $P-(S, S, S)-(S, S, S)-$, $M$ $(S, S, S)-(S, S, S)-, P-(S, S, S)-(R, R, R)-$ and $M-(S, S, S)-(R, R, R)-$ stereoisomers of the cage 18 were obtained in one step by reacting one equivalent of vanadium oxytriisopropoxide with the desired ligand through the coordination of the trialkanolamine moieties (Scheme 16). ${ }^{37}$

Once engaged in the oxidation of sulfide substrates, these optically pure catalysts displayed strong improvement of the catalytic activities (compared to their parent model devoid of the cavity), as well as remarkable substrate selectivity behavior (Scheme 16, a) ${ }^{37}$ Despite their promising first and second chiral coordination spheres, no asym- metric oxidation was detected with all four stereoisomers of 18. However, it should be noted that replacing the northern CTV moiety by a simple phenyl substituent, as in $\mathbf{4 2}$ (Scheme 16, b), led to the formation of a bowl-shaped oxidovanadium catalyst capable of catalyzing the direct asymmetric oxidation of thioanisole with $19 \%$ ee in an $83 \%$ yield. ${ }^{38}$

The scope of the synthetic strategy based on resolved $M$ - and P-stereoisomers of $\mathrm{CTV}\left(\mathrm{CH}_{2} \mathrm{CH}_{2} \mathrm{Br}\right)_{3}$ was also extended to the synthesis of the novel optically pure $M$ - and $P$-(S,S,S)-43 open structures (Scheme 17). ${ }^{39}$

The latter were used as references to unambiguously determine the absolute configuration of four novel open CTV hosts: $M$ - and $P-(S, S, S)-\mathbf{4 3}$ and $M$ - and $P-(R, R, R)-43$. These architectures were designed to compare the ability of

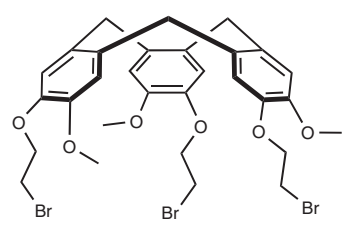

$(P)-\mathrm{CTV}\left(\mathrm{CH}_{2} \mathrm{CH}_{2} \mathrm{Br}\right)_{3}$

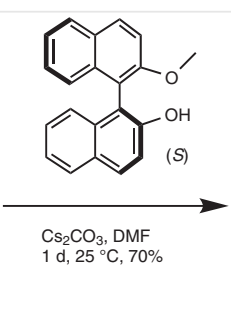

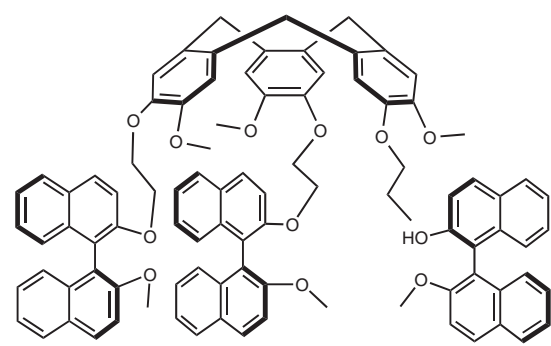

$(P)-(S, S, S)-43$

Scheme 17 Synthesis of $(S, S, S)-(S, S, S)-43$ 
open- and close-shell CTV-BINOL-based enantiopure receptors (Figure 5) to efficiently recognize and bind biologically relevant substrates (carbohydrates). ${ }^{24}$ Interestingly, improved enantio- and diastereoselectivities were observed for the closed hemicryptophanes $\mathbf{2 0}$ (see Section 2.1) compared to their open counterparts, highlighting the crucial role of the cage-like organic architecture.

Finally, an interesting example of optically pure hemicryptophanes, prepared from an optically resolved CTV precursor, was described back in 2010 by Diederich, Thilgen and co-workers. ${ }^{40}$ The chiral functionalization of an achiral $\mathrm{C}_{60}$ fullerene by an enantiomerically pure CTV-malonate $\mathbf{4 4}$ was achieved by means of a triple Bingle addition yielding the targeted chiral hemicryptophane structures $\mathbf{4 5}$ and $\mathbf{4 6}$ (Scheme 18). The CTV-malonate intermediate $\mathbf{4 4}$ arises from the derivatization of an optically pure CTV(triol $)_{3}$ precursor that had been previously resolved by chiral HPLC. The authors reported the formation of the four CTV $-\mathrm{C}_{60}$ conjugates, (-)-45a, (+)-45b, (+)-46a, and (-)-46b, which were isolated and fully characterized by means of ${ }^{1} \mathrm{H}$ NMR, ${ }^{13}$ C NMR, HRMS-MALDI-TOF, UV/Vis, ECD (Electronic Circular Dichroism) and VCD (Vibrational Circular Dichroism) analysis.

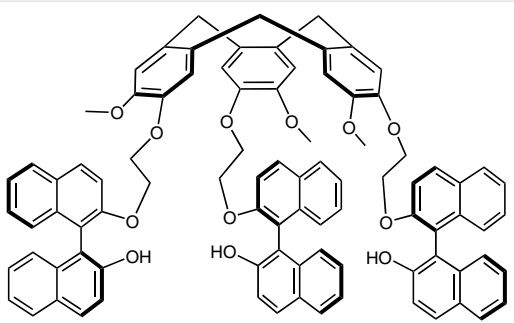

$(M)-(S, S, S)-43$

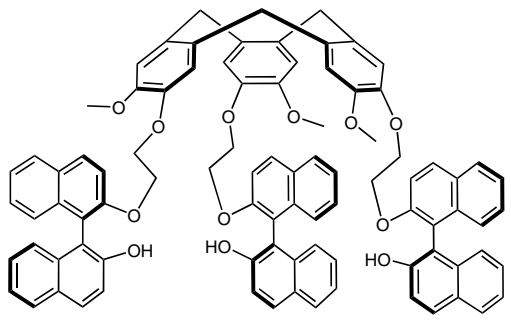

$(M)-(R, R, R)-43$

b)
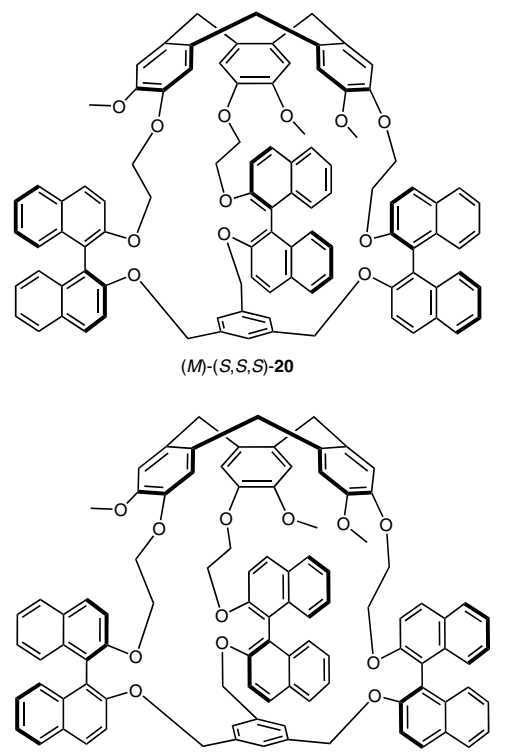

$(M)-(R, R, R)-20$

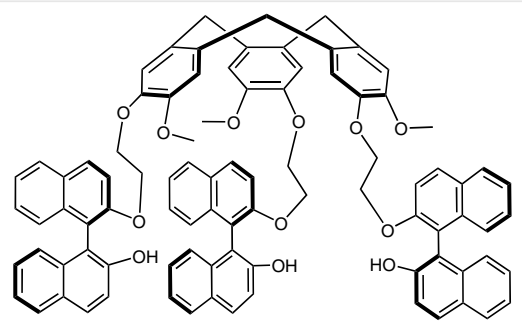

$(P)-(R, R, R)-43$

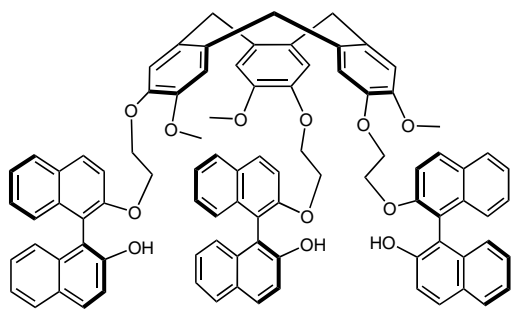

$(P)-(S, S, S)-43$
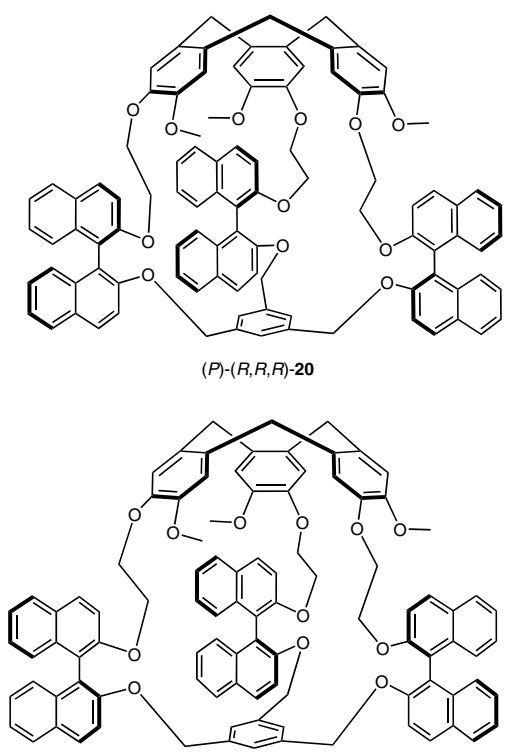

$(P)-(S, S, S)-20$

Figure 5 (a) Structures of the four stereoisomers of 43. (b) The corresponding closed-shell hemicryptophanes 20 

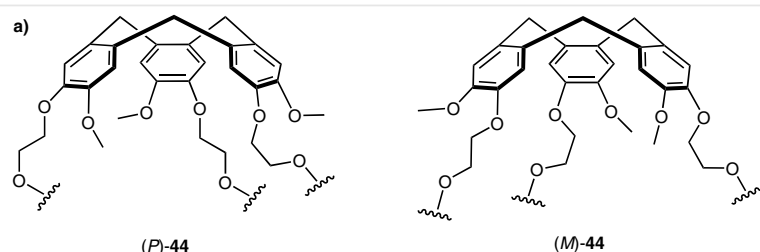

b)
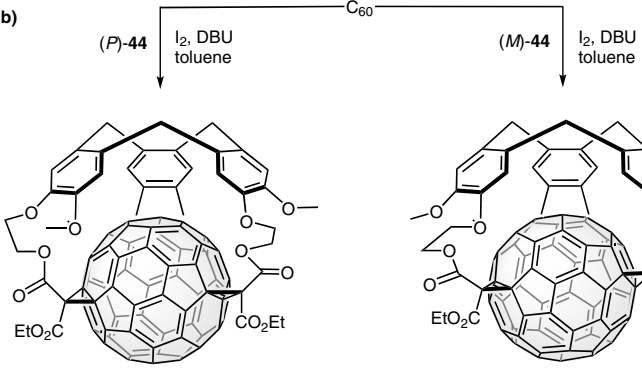

$(-)-45 a$
$10 \%$

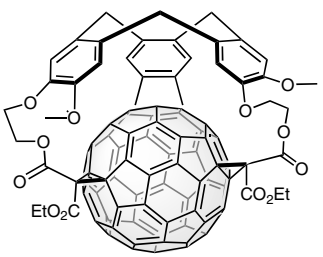

$\underset{8 \%}{(+)-46 a}$

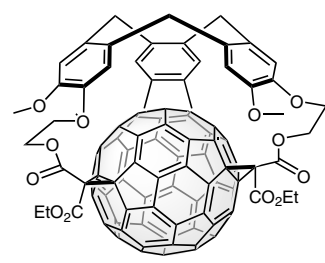

$(+)-45 b$

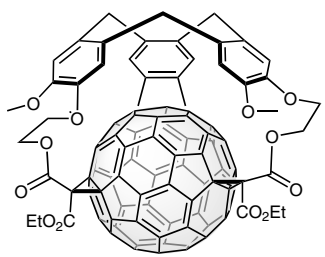

$\stackrel{(-)-46 b}{8 \%}$

Scheme 18 (a) Structures of the $M$ - and $P$-enantiomers of 44. (b) A mixture of the 4 enantiomers obtained by the addition of $(M)-44$ or $(P)$ 44 to $C_{60}$.

The exclusive formation of four isomers among the eight theoretically expected $\left(2^{3}\right)$ indicated the exclusive formation of the trans-3, trans-3, trans-3 tris adducts, and attests to the complete regioselectivity of the Bingle addition without racemization of the $P$ - or $M$-stereoisomers of $\mathbf{4 4}$. However, it should be noted that the amounts of the $P$ - and $M$-isomers of the CTV(triol $)_{3}$ precursors that could be isolated by chiral HPLC were low, with only $32 \mathrm{mg}$ of each enantiomer obtained after several injections. Therefore, only small quantities (ranging from 3.4 to $5.0 \mathrm{mg}$ ) of the four CTV- $\mathrm{C}_{60}$ adducts (-)-45a, (+)-45b, (+)-46a, and (-)-46b were obtained, illustrating the difficulty in obtaining large amounts of enantiomerically pure hemicryptophanes.

\section{Conclusion}

In summary, this short review highlights the recent work related to optically pure hemicryptophane architectures and provides an overall view of the synthetic approaches available for their preparation and purification.

Two main strategies have been classically applied in order to obtain enantiopure hemicryptophanes. The first approach, consisting of the introduction of stereogenic centers to generate diastereomers, was originally considered in order to avoid chiral separation of enantiomers. Following this strategy, covalent structures connecting a CTV unit with enantiopure trialkanolamine, TREN, BINOL, trialkanol, cyclic peptide and $\alpha$-cyclodextrin derivatives have been obtained by following a 'template approach' (hemicryptophane closure by intramolecular cyclization) or a [1+1] intermolecular coupling strategy. However, this approach suffers from complicated synthetic pathways, which often limits its versatility.

While initially considered a challenging task, the chiral separation of hemicryptophane enantiomers has lately become an attractive alternative due to the considerable progress achieved in the field of chiral HPLC purification techniques. Indeed, numerous separations of enantiopure hemicryptophanes, displaying versatile structures, have been recently achieved on relatively comfortable scales (hundreds of milligrams), highlighting the powerful and practical nature of chiral HLPC-based optical resolution. Importantly, the optical resolution of a key CTV intermediate, prior to building the desired hemicryptophane cage, was demonstrated to be a particularly efficient alternative approach. Following this second approach, elaborated hemicryptophanes could be conveniently obtained on gram scale over a reaction period of one week.

Altogether, these two different approaches allow for an easier and more straightforward access to enantiopure hemicryptophanes. We therefore believe that this review might $(i)$ attract the attention of synthetic chemists toward the construction of chiral supramolecular architectures, and (ii) allow for an easier choice between the existing solutions to obtain enantiopure capsules.

(1) (a) Fischer, E. Ber. Dtsch. Chem. Ges. 1894, 27, 2985. (b) Steed, J. W.; Atwood, J. L. Supramolecular Chemistry; John Wiley \& Sons: Chichester, 2009.

(2) (a) Chen, L. J.; Yang, H. B.; Shionoya, M. Chem. Soc. Rev. 2017, 46, 2555. (b) Beuerle, F.; Bappaditya, G. Angew. Chem. Int. Ed. 2018, $57,4850$.

(3) Saalfrank, R. W.; Scheurer, A. Top. Curr. Chem. 2012, 319, 125.

(4) Jędrzejewska, H.; Szumna, A. Chem. Rev. 2017, 117, 4863.

(5) Zhang, D.; Ronson, T. K.; Nitschke, J. R. Acc. Chem. Res. 2018, 51 , 2423.

(6) Brown, C. J.; Toste, F. D.; Bergman, R. G.; Raymond, K. N. Chem. Rev. 2015, 115, 3012. 
(7) Ousaka, N.; Grunder, S.; Castilla, A. M.; Whalley, A. C.; Stoddart, J. F.; Nitschke, J. R. J. Am. Chem. Soc. 2012, 134, 15528.

(8) Henkelis, J. J.; Carruthers, C. J.; Chambers, S. E.; Clowes, R.; Cooper, A. I.; Fisher, J.; Hardie, M. J. J. Am. Chem. Soc. 2014, 136, 14393.

(9) Schaly, A.; Rousselin, Y.; Chambron, J.-C.; Aubert, E.; Espinosa, E. Eur. J. Inorg. Chem. 2016, 832.

(10) (a) Wierzbicki, M.; Jędrzejewska, H.; Szumna, A. Chiral Calixarenes, In Elsevier Reference Module in Chemistry, Molecular Sciences and Chemical Engineering; Elsevier: Waltham (MA, USA), 2014. (b) Iwamoto, K.; Shimizu, H.; Shinkai, S. J. Am. Chem. Soc. 1993, 115, 3997. (c) Karpus, A.; Yesypenko, O.; Boiko, V.; Daran, J.-C.; Voitenko, Z.; Kalchenko, V.; Manoury, E. J. Org. Chem. 2018, 83, 1146. (d) Tlustý, M.; Slavík, P.; Kohout, M.; Eigner, V.; Lhoták, P. Org. Lett. 2017, 19, 2933. (e) Talotta, C.; Gaeta, C.; Troisi, F.; Monaco, G.; Zanasi, R.; Mazzeo, G.; Rosini, C.; Neri, P. Org. Lett. 2010, 12, 2912. (f) Slavik, P.; Kohout, M.; Bohm, S.; Eigner, V.; Lhotak, P. Chem. Commun. 2016, 52, 2366. (g) Aragay, G. G.; Ballester, P. Chem. Sci. 2016, 7, 5976.

(11) (a) Szumna, A. Chem. Soc. Rev. 2010, 39, 4274. (b) Cram, D. J.; Karbach, S.; Kim, H. E.; Knobler, C. B.; Maverick, E. F.; Ericson, J. L.; Helgeson, R. C. J. Am. Chem. Soc. 1988, 110, 2229. (c) Moran, J. R.; Karbach, S.; Cram, D. J. J. Am. Chem. Soc. 1982, 104, 5826. (d) Soncini, P.; Bonsignore, S.; Dalcanale, E.; Ugozzoli, F. J. Org. Chem. 1992, 57, 4608. (e) Beyeh, N. K.; Fehér, D.; Luostarinen, M.; Schalley, C. A.; Rissanen, K. J. Inclusion Phenom. Macrocyclic Chem. 2006, 56, 381. (f) Shivanyuk, A.; Rissanen, K.; Körner, S. K.; Rudkevich, D. M.; Rebek, J. Jr. Helv. Chim. Acta 2000, 83, 1778. (g) Vachon, J.; Harthong, S.; Dubessy, B.; Dutasta, J.-P.; Vanthuyne, N.; Roussel, C.; Naubron, J.-V. Tetrahedron: Asymmetry 2010, 21, 1534. (h) Vachon, J.; Harthong, S.; Jeanneau, E.; Aronica, C.; Vanthuyne, N.; Roussel, C.; Dutasta, J.-P. Org. Biomol. Chem. 2011, 9, 5086. (i) Concilio, G.; Talotta, C.; Gaeta, C.; Neri, P.; Monaco, G.; Zanasi, R.; Tedesco, D.; Bertucci, C. J. Org. Chem. 2017, 82, 202. (j) Iwanek, W.; Stefańska, K.; Szumna, A.; Wierzbicki, M. RSC Adv. 2016, 6, 13027. (k) Grajda, M.; Wierzbicki, M.; Cmoch, P.; Szumna, A. J. Org. Chem. 2013, 78, 11597. (l) Wierzbicki, M.; Głowacka, A. A.; Szymański, M. P.; Szumna, A. Chem. Commun. 2017, 53, 5200.

(12) Kobayashi, K.; Yamanaka, M. Chem. Soc. Rev. 2015, 44, 449.

(13) (a) Huc, I. Eur. J. Org. Chem. 2004, 1, 17. (b) Ferrand, Y.; Kendhale, A. M.; Kauffmann, B.; Grélard, A.; Marie, C.; Blot, V.; Pipelier, M.; Dubreuil, D.; Huc, I. J. Am. Chem. Soc. 2010, 132, 7858. (c) Ferrand, Y.; Chandramouli, N.; Kendhale, A. M.; Aube, C.; Kauffmann, B.; Grélard, A.; Laguerre, M.; Dubreuil, D.; Huc, I. J. Am. Chem. Soc. 2012, 134, 11282. (d) Tsiamantas, C.; de Hatten, X.; Douat, C.; Kauffmann, B.; Maurizot, V.; Ihara, H.; Takafuji, M.; Metzler-Nolte, N.; Huc, I. Angew. Chem. Int. Ed. 2016, 55, 6848. (e) Chandramouli, N.; Ferrand, Y.; Lautrette, G.; Kauffmann, B.; Mackereth, C. D.; Laguerre, M.; Dubreuil, D.; Huc, I. Nat. Chem. 2015, 7, 334.

(14) (a) Brotin, T.; Dutasta, J.-P. Chem. Rev. 2009, 109, 88. (b) El-Ayle, G.; Holman, K. T. Cryptophanes, In Comprehensive Supramolecular Chemistry II; Atwood, J. L.; Gokel, G. W.; Barbour, L. J., Ed.; Elsevier: New York, 2017. (c) Jenkelis, J. J.; Hardie, M. J. Chem. Commun. 2015, 51, 11929. (d) Oldknow, S.; Martir, D. R.; Pritchard, V. E.; Blitz, M. A.; Fishwick, C. W. G.; Zysman-Colman, E.; Hardie, M. J. Chem. Sci. 2018, 9, 8150. (e) Kai, S.; Kojima, T.; Thorp-Greenwood, F. L.; Hardie, M. J.; Hiraoka, S. Chem. Sci. 2018, 9, 4104. (f) Brégier, F.; Hudeček, O.; Chaux, F.; Penouilh, M.-J.; Chambron, J.-C.; Lhoták, P.; Aubert, E.; Espinosa, E. Eur. J. Org. Chem. 2017, 3795. (g) Joseph, A. I.; Lapidus, S. H.; Kane, C. M.; Holman, K. T. Angew. Chem. Int. Ed. 2015, 54, 1471. (h) Rose,
H. M.; Witte, C.; Rossella, F.; Klippel, S.; Freund, C.; Schröder, L. Proc. Natl. Acad. Sci. U.S.A. 2014, 111, 11697. (i) Kotera, N.; Tassali, N.; Léonce, E.; Boutin, C.; Berthault, P.; Brotin, T.; Dutasta, J.-P.; Delacour, L.; Traoré, T.; Buisson, D.-A.; Taran, F.; Coudert, S.; Rousseau, B. Angew. Chem. Int. Ed. 2012, 51, 4100. (j) Riggle, B. A.; Wang, Y.; Dmochowski, I. J. J. Am. Chem. Soc. 2015, 137, 5542. (k) Brotin, T.; Jeanneau, E.; Berthault, P.; Léonce, E.; Pitrat, D.; Mulatier, J.-C. J. Org. Chem. 2018, 83, 14465. (1) Chapellet, L.-L.; Cochrane, J. R.; Mari, E.; Boutin, C.; Berthault, P.; Brotin, T. J. Org. Chem. 2015, 80, 6143.

(15) (a) Crini, G. Chem. Rev. 2014, 114, 10940. (b) Engeldinger, E.; Armspach, D.; Matt, D. Chem. Rev. 2003, 103, 4147. (c) Gingter, S.; Bezdushna, E.; Ritter, H. Beilstein J. Org. Chem. 2011, 7, 204. (d) Gramage-Doria, R.; Armspach, S.; Matt, D. Coord. Chem. Rev. 2013, 257, 776. (e) Pedersen, C. M.; Bols, M. Cyclodextrin-Based Artificial Enzymes: Synthesis and Function, In Organic Synthesis and Molecular Engineering; Nielsen, M. B., Ed.; John Wiley \& Sons: Hoboken, 2014, 305. (f) Marinescu, L.; Bols, M. Curr. Org. Chem. 2010, 14, 1380. (g) Jouffroy, M.; Gramage-Doria, R.; Sémeril, D.; Armspach, D.; Matt, D.; Oberhauser, W.; Toupet, L. Beilstein J. Org. Chem. 2014, 10, 2388. (h) Jouffroy, M.; Armspach, D.; Matt, D. Dalton Trans. 2015, 44, 12942. (i) Jouffroy, M.; Gramage-Doria, R.; Armspach, D.; Sémeril, D.; Oberhauser, W.; Matt, D.; Toupet, L. Angew. Chem. Int. Ed. 2014, 53, 3937. (j) Guitet, M.; Zhang, P.; Marcelo, F.; Tugny, C.; Jiménez-Barbero, J.; Buriez, O.; Amatore, C.; Mouriès-Mansuy, V.; Goddard, J.-P.; Fensterbank, J.; Zhang, Y.; Roland, S.; Ménand, M.; Sollogoub, M. Angew. Chem. Int. Ed. 2013, 52, 7213. (k) Zhang, P.; Tugny, C.; Meijide Suárez, J.; Guitet, M.; Derat, E.; Vanthuyne, N.; Zhang, Y.; Bistri, O.; Mouriès-Mansuy, V.; Ménand, M.; Roland, S.; Fensterbank, L.; Sollogoub, M. Chem 2017, 3, 174. (l) Zhang, P.; Meijide Suárez, J.; Driant, T.; Derat, E.; Zhang, Y.; Ménand, M.; Roland, S.; Sollogoub, M. Angew. Chem. Int. Ed. 2017, 56, 10821.

(16) (a) Zhiquan, L.; Polen, S.; Hadad, C. M.; RajanBabu, T. V.; Badjić, J. D. J. Am. Chem. Soc. 2016, 138, 8253. (b) Chen, S.; Yamasaki, M.; Shane, P.; Gallucci, J.; Hadad, C. M.; Badjić, J. D. J. Am. Chem. Soc. 2015, 137, 12276. (c) Chen, S.; Ruan, Y.; Brown, J. D.; Hadad, C. M.; Badjić, J. D. J. Am. Chem. Soc. 2014, 136, 1733. (d) Chen, S.; Ruan, Y.; Brown, J. D.; Gallucci, J.; Maslak, V.; Hadad, C. M.; Badjić, J. D. J. Am. Chem. Soc. 2013, 135, 14964. (e) Zhiquan, L.; Xie, H.; Border, S. E.; Gallucci, J.; Pavlović, R. Z.; Badjić, J. D. J. Am. Chem. Soc. 2018, 140, 11091.

(17) Dalla Cort, A.; Mandolini, L.; Pasquini, C.; Schiaffino, L. New J. Chem. 2004, 28, 1198

(18) (a) Canceill, J.; Collet, A.; Gabard, J.; Kotzyba-Hibert, F.; Lehn, J.M. Helv. Chim. Acta 1982, 65, 1894. (b) Zhang, D.; Martinez, A.; Dutasta, J.-P. Chem. Rev. 2017, 117, 4900.

(19) (a) Hardie, M. J. Chem. Soc. Rev. 2010, 39, 516. (b) Canceill, J.; Collet, A.; Gabard, J.; Gottarelli, G.; Spada, G. P. J. Am. Chem. Soc. 1985, 107, 1299.

(20) Gautier, A.; Mulatier, J.-C.; Crassous, J.; Dutasta, J.-P. Org. Lett. 2005, 7, 1207.

(21) Perraud, O.; Martinez, A.; Dutasta, J.-P. Chem. Commun. 2011, 47, 5861.

(22) Schmitt, A.; Perraud, O.; Payet, E.; Chatelet, B.; Bousquet, B.; Valls, M.; Padula, D.; Di Bari, L.; Dutasta, J.-P.; Martinez, A. Org. Biomol. Chem. 2014, 12, 4211.

(23) Zhang, D.; Mulatier, J.-C.; Cochrane, J. R.; Guy, L.; Gao, G.; Dutasta, J.-P.; Martinez, A. Chem. Eur. J. 2016, 22, 8038

(24) Lefevre, S.; Simonet, R.; Pitrat, D.; Mulatier, J.-C.; Vanthuyne, N.; Jean, M.; Dutasta, J.-P.; Guy, L.; Martinez, A. ChemistrySelect 2016, 1, 6316. 
(25) Cochrane, J. R.; Schmitt, A.; Wille, U.; Hutton, C. A. Chem. Commun. 2013, 49, 8504.

(26) Brégier, F.; Karuppannan, S.; Chambron, J.-C. Eur. J. Org. Chem. 2012, 10, 1920.

(27) Chatelet, B.; Joucla, L.; Padula, D.; Bari, L. D.; Pilet, G.; Robert, V.; Dufaud, V.; Dutasta, J.-P.; Martinez, A. Org. Lett. 2015, 17, 500.

(28) Brégier, F.; Lavalle, J.; Chambron, J.-C. Eur.J. Org. Chem. 2013, 13, 2666.

(29) Perraud, O.; Dimitrov Raytchev, P.; Martinez, A.; Dutasta, J.-P. Chirality 2010, 22, 885.

(30) Dimitrov Raytchev, P.; Martinez, A.; Gornitzka, H.; Dutasta, J. P. J. Am. Chem. Soc. 2011, 133, 2157.

(31) Payet, E.; Dimitrov-Raytchev, P.; Chatelet, B.; Guy, L.; Grass, S.; Lacour, J.; Dutasta, J. P.; Martinez, A. Chirality 2012, 24, 1077.

(32) Zhang, D.; Bousquet, B.; Mulatier, J. C.; Pitrat, D.; Jean, M.; Vanthuyne, N.; Guy, L.; Dutasta, J. P.; Martinez, A. J. Org. Chem. 2017, 82, 6082.

(33) Canceill, J.; Collet, A.; Gottarelli, G.; Palmeri, P. J. Am. Chem. Soc. 1987, 109, 6454.
(34) Long, A.; Perraud, O.; Albalat, M.; Robert, V.; Dutasta, J.-P.; Martinez, A. J. Org. Chem. 2018, 83, 6301.

(35) Chatelet, B.; Payet, E.; Perraud, O.; Dimitrov-Raytchev, P.; Chapellet, L.-L.; Dufaud, V.; Martinez, A.; Dutasta, J.-P. Org. Lett. 2011, 13, 3706.

(36) Lefevre, S.; Zhang, D.; Godart, E.; Jean, M.; Vanthuyne, N.; Mulatier, J. C.; Dutasta, J. P.; Guy, L.; Martinez, A. Chem. Eur. J. 2016, 22, 2068.

(37) Zhang, D.; Jamieson, K.; Guy, L.; Gao, G.; Dutasta, J. P.; Martinez, A. Chem. Sci. 2017, 8, 789.

(38) Zhang, D.; Dutasta, J. P.; Dufaud, V.; Guy, L.; Martinez, A. ACS Catal. 2017, 7, 7340.

(39) Lefevre, S.; Héloin, A.; Pitrat, D.; Mulatier, J. C.; Vanthuyne, N.; Jean, M.; Dutasta, J. P.; Guy, L.; Martinez, A. J. Org. Chem. 2016, $81,3199$.

(40) Kraszewska, A.; Rivera-Fuentes, P.; Rapenne, G.; Crassous, J.; Petrovic, A. G.; Alonso-Gómez, J. L.; Huerta, E.; Diederich, F.; Thilgen, C. Eur. J. Org. Chem. 2010, 4402. 